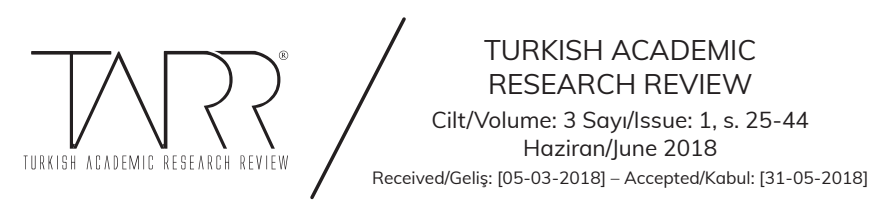

\title{
Beden, Mesken ve Bilgi Mahremiyeti Açısından Sosyal Medyadaki Tasarrufların Fıkhî Açıdan Değerlendirilmesi
}

Nilüfer Sena Çalık ${ }^{1}$

\section{Özet}

İnternet ilk ortaya çıktığı zamanlarda günümüzdeki gibi yaygın bir kullanım alanına sahip değildi. Mobil iletişim teknolojilerinin gelişmesi ile birlikte her an elimizin altında olan, hayatımızı kolaylaştıran birer araca dönüşmüştür. İnternetin bu derece yaygın kullanılmasında ve hayatımızın vazgeçilmez birer parçası hâline gelmesinde sosyal medya araçlarının etkisi göz ardı edilemeyecek kadar büyüktür. İnternet teknolojisinin hayatımıza girmesi ile birlikte fıkhî açıdan tartışılması gereken yeni meseleler ortaya çıkmıştır. Özellikle sosyal medya araçlarının hayatımızda bu derece etkin yer almaya başlaması sosyal medya üzerinde yeni tartı̧̧maları da beraberinde getirmiştir. Sosyal medyada mahremiyet algısı da bu yeni tartışma alanlarından birisidir.

Mahremiyet insana kendi kendisine kalabileceği, başkalarının gözetiminden uzak bir alan tesis etmektedir. Her koşulda korunması gereken bu mahremiyet algıs1nın sanal ortama gelindiğinde değişime uğradığı görülmektedir. Bu çalışmada Allah'ın bizi ve bedenlerimizi korumak adına mahremiyet kavramı ile nasıl bir sınır oluşturduğuna değinerek sosyal medya kullanıcılarının sosyal medya hesapları üzerinden bu sınırları nasıl ihlal ettiklerine ve fıkhi açıdan nasıl bir mahremiyet anlayışına sahip olmamız gerektiğini ortaya koymaya çalışacağız.

Anahtar kelimeler: Mahremiyet, fikıh, sosyal medya, internet, tesettür

\section{Evaluation of the Social Media Savings in Terms of Body, Dwelling and Knowledge Privacy}

\section{Abstract}

The Internet did not have a widespread use as of the time it first appeared. Along with the development of mobile communication technologies, it has been transformed into a vehicle that is under our control at all times, making life easier. The influence of social media tools on widespread use of internet is so gerat that it can not be ignored. Moreover, this makes internet an indispensible parts of our lives.

With the advent of Internet technology in our lives, new issues have emerged that need to be discussed in terms of jurisprudence. That social media tools have taken

1 Yüksek Lisans Öğr., Nilüfer Sena Çalık, secalik@hotmail.com 
an effective place on our lives bring new discussion area on social media. The sense of privacy in the social media is one of these discussed areas.

Privacy establishes a space that people can be left alone to themselves, far from others' supervision. This sense of privacy, which must be protected in every circumstance, seems to have changed when comes to virtual presence. This study aims the show that how social media users violate these boundaries through social media accounts and how we should have an understanding of privacy from the point of view of fiqh, referring to how Allah creates a boundary with the concept of privacy in order to protect us and our bodies.

Keywords: Privacy, Islamic Law, social media, internet, being covered

\section{GíRiş}

Sosyal medya kullanımının hızla arttığı günümüz modern dünyasında pek çoğumuz için güne Facebook, Twitter, Instagram gibi sosyal medya hesaplarını kontrol ederek başlamak sıradan birer ritüel haline gelmiştir. Hayatımızın bu kadar merkezinde olan ve bizi dört bir yandan kuşatan sosyal medya dünyasının biz kullanıcılarına çeşitli sorumluluklar yüklediğini bilmemiz gerekmektedir. Ancak pek çok kişinin sosyal medya üzerinde yaptığı paylaşımlarda bu bilinçte olmadığı görülmektedir.

Allah Teâlâ insanı "ahseni takvîm” üzere yarattığını belirtmiştir. ${ }^{2}$ Bu en güzel yaratılış biz kullar için birer lütuftur. En güzel şekilde yaratılmış olan insanın yaratılıştan gelen doğal özünü koruması ve ona sahip çıkması gerekmektedir. Bunu korumak adına Allah'ın tayin ettiği ilkelerden birisi mahremiyettir.

Mahremiyet, kişinin özgürlügüünün sınırlarını belirleyen bir kavramdır. Kişinin bedeni üzerindeki özgürlüğü Allah'ın belirlediği ilkeler dâhilindedir. Rabbimiz bedenlerimizi bize emanet olarak verdiği için bu emanetin nasıl korunması gerektiğini hem emretmiş hem de sınırlarını kendisi belirlemiştir. Bu hususta ayet-i kerimede Allah bizden "kendimizi ve ailemizi yakıtı insanlar ve taşlar olan ateşten korumamızı" istemektedir. ${ }^{3}$ Nitekim Müslüman bir kişinin sorumluluğu belli bir alanla sınırlı değildir. ${ }^{4}$ Mahremiyet kavramının önemi de bu noktada ortaya çıkmaktadir.

Sosyal medya günlük hayatta kullanıcılarına pek çok kolaylık sağlarken dikkatli kullanılmaması durumunda istenmeyen zararlı sonuçlara sebebiyet verebilmektedir. Bu zararların başında mahremiyet ihlalleri gelmektedir. Sosyal medyada beden mahremiyeti ${ }^{5}$, mesken mahremiyeti ${ }^{6}$, bilgi mahremiyeti ${ }^{7}$ ihlal edilmektedir.

Bkz. Tin, 95/4.

Tahrîm, 66/6.

4 Hayreddin Karaman v. dğr., Kur'an Yolu Türkçe Meâl ve Tefsir, Ankara: Diyanet İşleri Başkanlığı Yayınları, c. V (2008), s.409.

5 Nûr, 24/30, Ahzab, 33/59.

6 Nûr, 24/27, Ahzab, 33/53.

7 Hicr, 15/18, Mücadele,58/ 8.

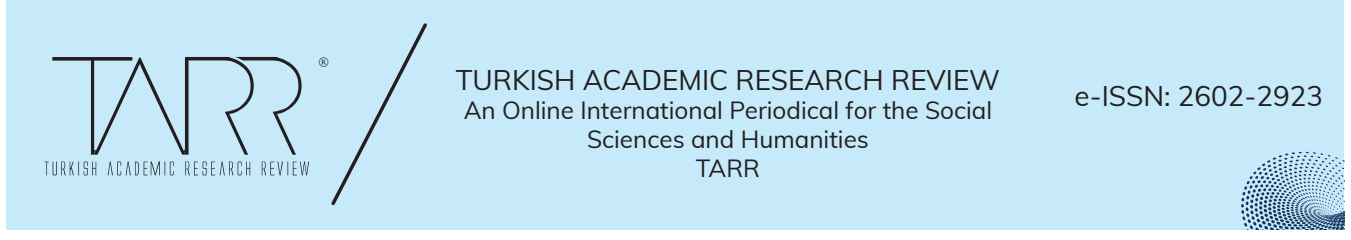


Bunun yanında kendini ifşa ${ }^{8}$, tecessüs, grybet ${ }^{9}$ ve daha pek çok husus bu sanal ortamlarda hizla yayılmaktadir. Bunun sonucu olarak Allah'in bize bedenlerimizi korumamız adına tahsis ettiği mahremiyet kavramı hızla değerini kaybetmektedir. Çoğu zaman yapıp ettiklerimiz ile sınırlarını aştığımızın bile farkına varamadığımız mahremiyet önce sosyal medyada sonra da günlük hayatta sadece ismen varlığını sürdüren, içi boşaltılmış bir kavram haline getirilmiştir.

Biz bu çalışmamız ile sosyal medyada değişime uğrayan mahremiyet anlayışının fıkhi açıdan tahlilini yapmaya çalışacağız. Sosyal medyada ne tür mahremiyet ihlallerinin olduğunu, bedenlerimizi, evlerimizi yani en mahrem hallerimizi sosyal medya hesapları üzerinden nasıl görünür kıldığımıza dikkat çekerek "Sosyal medya üzerinde mahremiyeti yeniden nasıl sağlayabiliriz?” sorusunu kendimize sormamızı sağlayacağız.

Çalışmamızda öncelikle sosyal medyanın ortaya çıkışını ele alıp ardından mahremiyet kavramına değindikten sonra sosyal medyada nasıl bir mahremiyet anlay1şına sahip olmamız gerektiğine değineceğiz.

\section{Geleneksel Medyadan Sosyal Medyaya Geçiş}

İletişimin tarihi insanlık tarihi ile eş tutulmaktadır. İlkel yöntemler ile başlayan iletişim araçlarının sosyal medyanın ortaya çıkışına kadar sürekli bir gelişim gösterdiği görülmektedir. Ateş ve duman ile başlayan bu süreç kâğıdın ve yazının icadı ile birlikte ilk önemli dönüşümü yaşamıştır. Zamanla iletişimdeki yazı öğesine ses ve görsel içeriklerin de eklenmesi ile birlikte iletişim araçlarının kullanım alanı genişlemiştir. Medya olarak isimlendirilen radyo, dergi, televizyon gibi iletişim araçları ${ }^{10} 21$. yüzyıla gelindiğinde artık geleneksel yapısından sıyrılarak yeni bir şekle dönüşmeye başlamıştır. ${ }^{11}$ Bu dönüşüm yeni medya olarak isimlendirilirken bu yenilik, paylaşılan içeriğin geleneksel medyanın aksine sosyal bir ortamda gerçekleşmesinden kaynaklanmaktadır. Böylece yeni medya olarak isimlendirilen sosyal medya kullanıcılarına etkileşimli bir iletişim ortamı sunmayı hedeflemiştir. ${ }^{12}$

Sosyal medya, içeriğini kullanıcıların oluşturduğu her türlü ağ siteleri, bloglar, görsel içerik paylaşım araçlarının bütününü ifade eden bir kavramdır. ${ }^{13}$ Sosyal medyanın ortaya çıkışını ve özellikle medyanın modern şekle dönüşmesini sağlayan ilk gelişme kuşkusuz internetin bulunuşu olmuştur. İnternet teknolojisi evlerimize girdikten sonra Six Degrees ile başlayan ve günümüzde yaygın olarak kullanılan Facebook, Twitter, Instagram gibi sosyal medya araçlarının yaygınlaşmasına kadar geçen süreçte sosyal medya kendisini geliştirmiş ve kullanıcıları da etkisi altına alarak geniş bir kapsama alanı kazanmıştır.

8 Nûr, $24 / 19$.

9 Hucurât, 49/12.

10 Fatih Özutku v. dğr., Sosyal Medyanın ABC’si (İstanbul: Alfa Yayınları, 2014), s. 9.

11 Mehmet Kartal, “Türkiye’de Sosyal Medya Raporu”, Illetişim ve Diplomasi Dergisi, s. 1 (2013), s. 159.

12 Şerife Öztürk, "Sosyal Medyada Etik Sorunlar”, Selçuk İletişim Dergisi, c. I, s. 9 (2015), s. 289.

13 Nagihan Tufan Yeniçıktı, Sosyal Medya Facebook ve Twitter Motivasyonları, (Konya: Literatürk Akademi, 2017), s. 113.

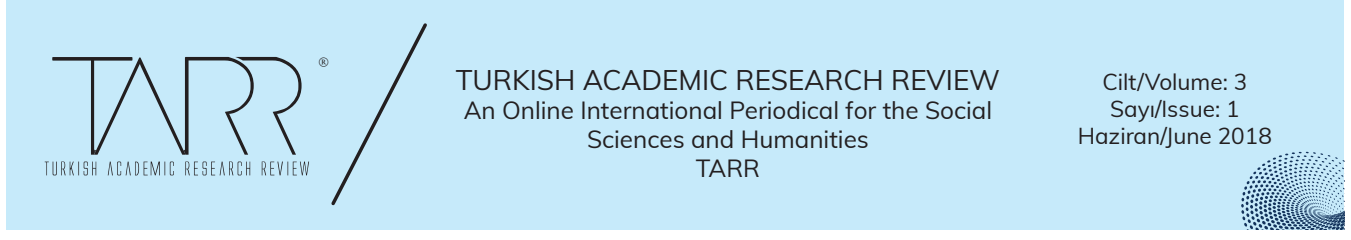


Sosyal medya dünyada en etkili ve en yaygın kullanılan iletişim araçlarının başında gelmektedir. Sosyal medyanın bu kadar yaygın ve etkili olmasının nedeni çoklu kullanım özelliğidir. Yani diğer iletişim araçlarında olduğu gibi sadece iletişim sağlamakla kalmayan sosyal medya, aynı zamanda sisteme yüklenen verileri saklama görevi de görmektedir. Bu veriler, gerektiğinde kullanıcıların hizmetine sunularak karşılıklı bilgi akışı sağlanmaktadır. ${ }^{14}$

Yeni medya veya sosyal medya olarak isimlendirilen Facebook, Twitter gibi sosyal medya araçları içinde bulunduğumuz çağda en yaygın kullanılan sosyal medya araçları olup kullanıcılar zamanlarının çoğunu bu ortamlarda tüketerek Facebook'un “Ne yapıyorsun?”, Twitter'ın “Neler oluyor?” sorularına verecekleri cevabı aramaktadırlar. Bunun yanında artık pek çok kişi haberleşmek için genellikle sosyal medya araçlarını tercih etmektedir. Özel gün davetleri bu ortamlarda oluşturulan etkinlikler ile duyurulurken, dini öneme sahip özel geceler sosyal medya hesapları üzerinden paylaşılan, anlamı iki cümleye indirgenen paylaşımlardan ibaret hale gelmiştir.

Sosyal medyayı geleneksel medyadan ayıran en önemli özelliğin ne olduğu sorusuna gelecek olursak bu soruya verilecek cevap kuşkusuz sosyal medyanın kendine has, özgür paylaşım ortamıdır. Kullanıcılar istedikleri gönderiyi herhangi bir engel veya sınırlamaya maruz kalmadan paylaşabilirken, sosyal medyanın aksine geleneksel medyada belli ritüeller gözümüze çarpmaktadır. Geleneksel medya araçlarında yayınlanması istenen bir haber yayın yönetmeninin izninden geçmeden yayınlanamayacağı gibi aynı şekilde yayınlanması istenen bir yazı editörün onayını almadan okuyucu ile buluşamazd. ${ }^{15}$ Geleneksel medyaya bakıldığında da basın özgürlüğü bulunurken bu, belli kurallar çerçevesinde gerçekleşmektedir. ${ }^{16}$ Sosyal medyanın diğer iletişim araçlarında olmayan bu özgür paylaşım ortamı, kullanıcıların istedikleri şeyleri paylaşmasının önünü açarken aslında bu durum farkına varılmasa da çeşitli sosyal medya ihlallerini beraberinde getirmektedir. Bu ihlaller Türk Ceza Kanunu'nda bilişim suçları adı altında 243. ve 246. maddeler arasında belirlenmiş ve kanunlaşmıștır. Bilişim suçları yanında özel hayatın gizliliğini ihlal eden kişilere yönelik suçlar da 132 . madde çerçevesince belirlenmiştir. ${ }^{17}$ Böylece hukuka aykırı işler yapan veya sistemin işleyişine zarar veren, başkasının özel hayatını ifşa eden kişilere verilecek cezalar kanunda belirtilmiştir.

Var olma arayışı içerisinde olan, kendisini ispat etmek isteyen, hayatın akışı içerisinde kendisine yer bulamamıs pek çok insan sosyal medya hesapları üzerinde oluşturdukları profil ile kendi varlıklarını kolayca ispat edebilir hale gelmiştir. ${ }^{18}$ Bunun yanında internet erişimi sağlandığı takdirde herhangi bir maliyet gerek-

14 Lokman Cerrah, "Sosyal Medya ve Bazı Kurumsal Etkileşimler ve Sosyal Medyaya Eleștirel Yaklaşım”, Atatürk Üniversitesi Sosyal Bilimler Enstitüsü Dergisi, c. IV, s. 20 (2016), s. 1394.

15 Mehmet Emin Babacan, İrfan Haşlak, İsmail Hira,"Sosyal Medya ve Arap Baharı", Akademik Incelemeler Dergisi, c. VI, s. 2 (2011), s. 72-73.

16 Bilgi için bkz. http://www.mevzuat.gov.tr/Metin.Aspx?MevzuatKod=1.5.5187\&Mevzuatlliski=0\&sourceXmlSearch $=$, (22.05.18).

17 http://www.mevzuat.gov.tr/MevzuatMetin/1.5.5237.pdf , (23.05.18).

18 Murat Dağıtmaç, Sosyal Medya Bizi Neden Kullanır (İstanbul: Metafoz Yayınları, 2015), s. 27.

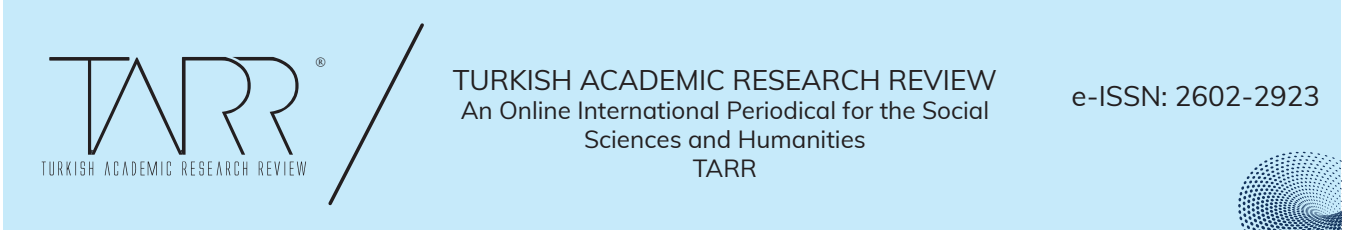


tirmemesi, geleneksel medyaya kıyasla oldukça hızlı oluşu, geniş toplulukları etkileme gücüne sahip olması ${ }^{19}$ sosyal medya kullanımını daha da cazibeli hale getirmiştir.

2018 yılında We Are Social tarafindan hazırlanan "Digital in 2018 Global Owerview” raporu verilerine göre dünya nüfusu 7.593 milyar olarak tespit edilmiştir. Bu nüfusun 4.021 milyarı internet kullanıcısı iken 3.196 milyar insan aktif sosyal medya kullanıcısıdır. ${ }^{20} \mathrm{Bu}$ oranlar bize açıkça sosyal medyanın insanlar üzerinde ne kadar etkili olduğunu göstermektedir. Dünya nüfusunun \%42'sinin sosyal medya kullanıcısı olduğu göz önünde bulundurulursa birkaç yıl içerisinde $r$ kişiden birinin sosyal medya kullanıcısı olacağını rahatlıkla söyleyebileceğiz. Bu oran bize sosyal medyanın hayatımızda ne kadar etkin rol oynadığını göstermektedir.

\section{Mahremiyet Kavramının Tesisi}

Allah Teâlâ Kur'an-1 Kerim'de geçen pek çok ayette insanın zaaflarından bahsetmektedir. ${ }^{21}$ İnsanı kuşatan bu zaaflar sadece belli bir konuda olmadığı gibi pek çok alanda karşımıza çıkmaktadır. Dünyaya gönderiliş amacı imtihan olan insanın mahremiyet alanının da kapsamına giren bu zaaflarının farkına vararak nefsini temiz tutması ve Allah'ın rızasını kazanacak davranışlarda bulunması gerekmektedir.

İnsan bedeni Allah'ın kullarına bıraktığı ve korunmasını istediği en önemli değerlerdendir. Allah'ın insana bıraktığı bu emaneti Kur'an-1 Kerim insanın yaratılıştaki güzelliğini ifade eden ayet-i kerime ile zaten dile getirmiştir. ${ }^{22}$ Allah kullarına verdiği değeri yalnızca onu en güzel şekilde yaratarak göstermekle kalmamıs aynı zamanda evreni onlar için yarattığını ${ }^{23}$ ve yeryüzünün kullanımını onların hizmetine sunduğunu da belirtmiştir. ${ }^{24} \mathrm{Bu}$ ayet-i kerimeler açıkça bize insanın ne kadar özel yaratıldığını ve şeref sahibi kılındığını göstermektedir. Allah, kullarına bu kadar ehemmiyet verip Âdemoğullarını mükerrem kıldığını ${ }^{\text {ro }}$ belirtirken biz bu değerlerin ne kadarının farkında olduğumuzu kendi içimizde sorgulamamız gerekmektedir.

İnsan yaratılış itibari ile iki kısımdan meydana gelmektedir. Birincisi insanın görünen kısmını oluşturan maddi varlığı yani vücut bütünlüğü iken ikincisi manevi varlığını oluşturan onuru ve şerefidir. İnsanın onurunu ve şerefini korumak adına Allah mahremiyet kavramını tesis etmiştir. ${ }^{\Upsilon}$

19 Özutku, a.g.e., s. 83-84.

20 https://wearesocial.com/blog/2018/01/global-digital-report-2018, erişim tarihi: 07.02.18.

21 Yusuf $12 / 53$, Nahl 16/4, Nisa $4 / 28$

22 Tin $95 / 4$.

23 Bakara $2 / 29$.

24 Câsiye $45 / 13$.

25 İsra $17 / 70$.

26 Tuba Öztürk, “Mahremiyet Sınırlarının Değișimi: Hz. Peygamber'in Özel Hayat Örneği”, Türkiye’de Tüm Yönleri ile Siyer Çalışmaları Sempozyum Tebliğler Kitabı I, (ed.) Hatice Sarı Tan, İstanbul: Meridyen Derneği Yayınları, c. I (2016), s. 153.

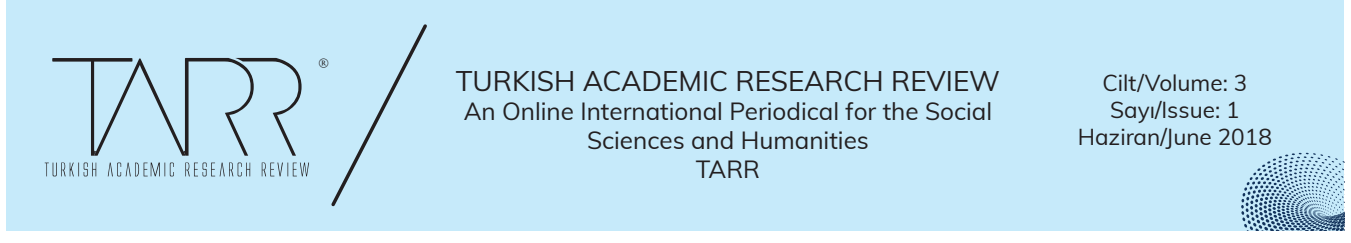


Mahremiyet kavramı İslam hukukunda genellikle günlük hayat içinde kadın ve erkek arasındaki ilişkinin sınırlarını çizen ve tesettür ölçüsünü belirleyen bir kavram olarak karşımıza çıkmaktadır. ${ }^{27}$ Klasik kaynaklara bakıldığında ise mahremiyet konusunun çerçevesinin oldukça geniş tutulduğu görülmektir. Özellikle aile hukukunda mahremiyet sıkça kullanılan bir terim olarak işlerlik kazanmıştır. Ancak bizim konumuzun kapsamı alanına giren mahremiyet kavramı daha çok insanların başkaları ile ilişkilerinde yüklenmesi gereken sorumluluk boyutu ile ilgilidir. ${ }^{\wedge} \wedge$

"Naslarda yer alan ameli hükümlerin gayelerini” içeren makâsıdü'ş-şeriâya ${ }^{29}$ göre beş husus İslam hukukunda güvence altına alınmıştır. Bunlar zaruri maslahatlar kısmına giren dinin, canın, aklın, neslin ve malın muhafazasıdır. Allah, toplum düzenini tesis etmek adına bu beş şer'i esası zorunlu kılıp haciyyât ve tahsîniyyât kapsamına giren maslahatlardan ayrı tutmuştur. İnsanın maddi ve manevi varlığ1nı oluşturan vücut bütünlüğü, onuru, şerefi ve haysiyeti de bu şer’i esaslar vasıtası ile koruma altına alınmıştır. Bu esaslar içerisinde canın muhafazası, insanın maddi varlığını korumaya yönelik şer’i bir hükümdür. Bunu gerçekleştirmek adına kısas ve tâ'zîr cezaları ${ }^{30}$ uygulamaya konulmuştur. İnsanın manevi varlığını oluşturan, insan onuru ve şerefini korumak adına ortaya konulan şer’i hükümlerden biri neslin muhafazasıyla alakalı hükümlerdir.

Allah, neslin muhafazasını sağlamak adına nikâhı emretmiştir. Çünkü nikâh kadın ve erkek arasında mahremiyetin korunmasını sağlamakta ve birbirlerine karş1 daha özgür davranmalarının önünü açmaktadır. ${ }^{31}$ Nikâh, evlenecek kişilere karşılıklı özgürlük alanı sunmakla beraber Allah, evleninceye kadar kullarından iffetlerini korumalarını istemiştir. ${ }^{32}$ Çünkü iffet haramdan sakınmayı gerektiren, nefsin aşağı duygularını yok ederek erdemli bir hayat sağlamayı temin eder. İffet, insan ruhunu terbiye ederek hazlara meyletmesini önlemekte ve insanın Allah'in rızasına uygun bir hayat sürdürmesine yardımcı olmaktadır. ${ }^{33}$

\section{Mahremiyet ve Fesad-I Zaman}

Haram kelimesinden türemiş olan "mahrem” lûgatta evlenilmesi yasak olan, nikâhlanması kendisine haram kılınan anlamına gelmektedir. ${ }^{34}$ Mahrem kelimesi ay-

27 Abdullah Kahraman, "Mahremiyetin Tanımı ve Sınırı”, Din Gelenek ve Ahlak Bağlamında Mahremiyet Alglları Sempozyumu, ed. Yavuz Ünal vd., (Samsun: Ordu İlahiyat Vakfı Yayını, 2015) C. I, s.33.

28 İsmail Güllük, "Avret Mahremiyeti Prensipleri Açısından Görüntü, Gerçeklik, Sanal Âlem ve Cinsellik üzerine Fıkhi Bir Analiz”, İslam Hukuku Araştırmaları Dergisi, s. 23 (2014), s. 106.

29 Ertuğrul Boynukalın, "Makâsıdü’ş-şerîa", Türkiye Diyanet Vakfı İslam Ansiklopedisi (DİA) (Ankara: Türkiye Diyanet Vakf1, 2003), XXVII, 423.

30 Yaşar Yiğit, İslam Ceza Hukuku Hükümlerin Yürürlüğü (Ankara: Sistem Ofset Yayıncılık, 2012), s. 38.

31 Fahrettin Atar, "Nikâh", Türkiye Diyanet Vakfı İslam Ansiklopedisi (DİA) (İstanbul: Türkiye Diyanet Vakf1, 2007), XXXIII, 112.

32 Nûr 24/33.

33 Mustafa Çağrıcı, “İffet”, Türkiye Diyanet Vakfı İslam Ansiklopedisi (DİA) (İstanbul: Türkiye Diyanet Vakf1, 2000), XXI, 506-507.

34 Ferit Devellioğlu, Osmanlıca-Türkçe Ansiklopedik Lûgat (2. bs., Ankara: y.y. 1970), s.680.

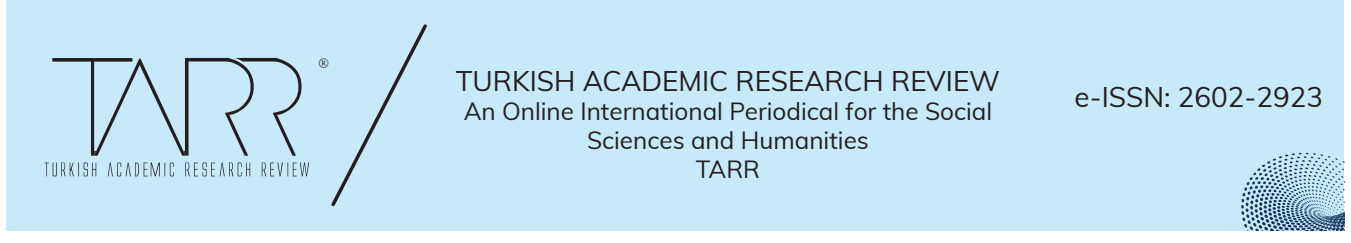


rıca "hürmet", "ihtiram" gibi anlamlarda da kullanılmaktadır. ${ }^{35}$ Yine aynı kökten türemiş olan mahremiyet kavramı ise İslam hukukuna göre "Şâri'in başkalarının ulaşmasına sınır koyduğu hak" ${ }^{36}$ şeklinde tanımlanır.

Yaşadığımız çağda değişim ve dönüşüm kaçınılmaz olarak varlığını sürdürmektedir. Her döneme etki eden bu değişim karşısında İslam hukukunun nasıl bir yöntem geliştirdiği bizim konuyu anlayabilmemiz açısından önem arz etmektedir. Bir tarafta batılılaşma eğilimleri, diğer taraftan teknolojik gelişmelerin birbirini takip etmesi zamanla hükümlerde değişime gidilmesi veya İslam hukukunda hükümlerin esnekleşmesi sorununu gündeme getirmiştir. ${ }^{37}$ Mahremiyetin sosyal medyada yaşadığı dönüşümü de bu şekilde fesad-ı zaman kavramı ile açıklayabiliriz. Yani mahremiyetin sosyal medyada değişim geçirmesi, nasları anlamaya çalışırken onları dönemin şartlarına uydurmak adına esnek davranmaktan kaynaklanmaktadır.

Modern hukuktaki mahremiyet algısı ile İslam hukukunun mahremiyet anlayışı birbirinden farklıdır. Temelde her ikisi de özgürlük ile ilişkilendirilse de modern hukuk anlayışında özgürlüğün sınırları kişinin kendi kontrolü dâhilindedir. Mahremiyet kapsamına giren hususları hangi ölçüde başkaları ile paylaşacağına kişi kendi iradesi dâhilinde karar verirken ${ }^{38}$ İslam hukukunda bu sinırlar vahiy tarafından belirlenmiştir. Yani modern hukukta sınırları belirleyen, fail konumunda olan insanın bizatihi kendisi iken İslam hukukunda bunun belirleyicisi Allah'tır.

İslam hukukundaki "Ezmânın tağayyürü ile ahkâmın tağayyürü inkâr olunamaz."39 şeklindeki Mecelle maddesi bize zamanın değişmesi ile birlikte ahkamın değişmesinin de kaçınılmaz olduğunu ifade etmektedir. Sosyal medya mahremiyetini de bu şekilde anlayıp anlayamayacağımız sorusu akıllara gelebilir. Değișen zaman, modernleşme, bununla birlikte hızla Batılılaşma tutkusunun neticesi olarak mahremiyette yaşanan dönüşümün zamanla ahkâmda meydana gelen değişim olarak görmenin sağlıklı bir bakış açısı olmadığını ifade etmemiz gerekmektedir. Yaşanan gelişmeler karşısında yeni hükümlerin ortaya konulması ise ahkâmın değişmesi değil, gelişmesi ile ilgili bir husustur. ${ }^{40}$

\section{Sosyal Medya ve Mahremiyet}

Sosyal medya hesapları bir kısım kullanıcı için günün yorgunluğunu atmak adına vakit geçirilen mekânlar iken, bir kısım kullanıcı için bilgi edinme aracı olarak görülmektedir. Bir kısım kullanıcı ise bu sanal ağları sosyalleşme aracı olarak

35 Mehmet Erdoğan, Fıkıh ve Hukuk Terimleri Sözlüğü (4. bs., İstanbul: Ensar Yayınları, 2013), s. 336.

36 İsmail Güllük, Avret Mahremiyeti Prensipleri Açısından Görüntü Gerçeklik, Sanal Âlem ve Cinsellik Üzerine Fıkhî Bir Analiz” İslam Hukuku Araştırmaları Dergisi, s. 23 (2014), s. 106.

37 Mehmet Erdoğan, İslam Hukukunda Ahkâmın Değişmesi (6. bs., İstanbul: Marmara Üniversitesi İlahiyat Vakf1 Yayınları, 2009), s. 225.

38 Mehmet Yüksel, “Mahremiyet Hakkı ve Sosyo-Tarihsel Gelişimi”, Ankara Üniversitesi SBF Dergisi, c. LVIII s. 1 (2003), s. 182.

39 Mecelle, md. 39.

40 Erdoğan, İslam Hukukunda Ahkâmın Değişmesi, s. 3.

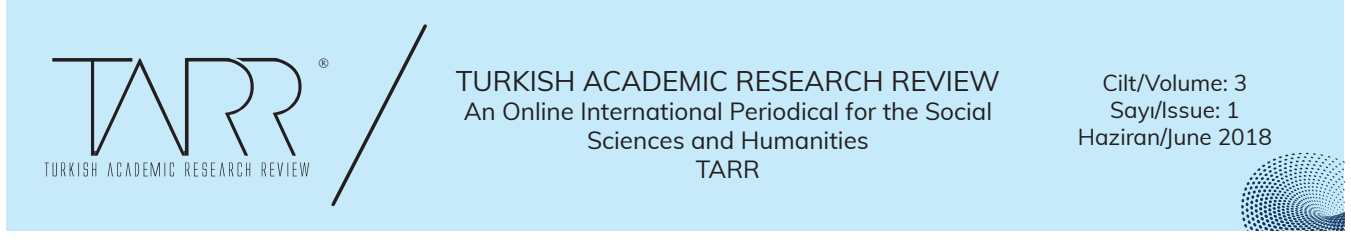


görmektedir. Her ne şekilde kullanılırsa kullanılsın günün belli bir kısmı bu sanal ağlar üzerinde geçtiğinden dolayı sosyal medya üzerindeki davranışlarımız ayrı bir önem arz etmektedir. Çünkü sosyal medya, geleneksel medyaya kıyasla yeni bir sorumluluk alanıdır.

Sosyal medya, herkesin üretici konumunda olduğu ve sürekli paylaşım yaptığ1 bir platformdur. Sosyal medya üzerinde yapılan paylaşımlarda daha çok görsel ağırlıklı paylaşımlar öne çıkmaktadır. Paylaşılan fotoğraflar ve videolar merak duygusunu harekete geçirerek kullanıcıları başkalarını daha çok takip etmeye ve kimin nerede ne yaptığı sorularına cevap bulmaya itmektedir. Aslında sosyal medya kullanıcılarının tümü görsel içerik paylaşmaya meyilli değildir. Ancak birilerini gözetleme, başkalarının durumunu araştırma sosyal medyada o kadar normalleşmiştir ki, kimi zaman kullanıcılar mevcut durumdan geri kalmamak adına sosyal medyaya meyletme eğilimine girerler. ${ }^{41}$

Günümüzde mahremiyet anlayışının geçirdiği değişimin önde gelen sebeplerinden birisi hızla gelişen teknoloji olarak görülmektedir. İnternet kullanımının yaygınlaşması ile birlikte insanlar artık kendi mahremiyetlerini kendileri yönetmeye başladıkları görülmektedir. Eskiden mahremiyet sınırları içerisinde görülen pek çok davranış günden güne o sınırları aşarak yeni bir boyut kazanmıştır. Artık pek çok davranışın normalleştiği yeni bir dönemden geçiyoruz. ${ }^{42}$

Mahremiyette yaşanan değişim ve dönüşümün tek sorumlusu teknoloji veya teknolojik gelişmelerin getirdiği imkânlar olarak görmek çok isabetli değildir. İlk insanlar göçebe bir yaşam tarzı sürerken, yerleşik yaşama geçmeleri ile birlikte kentleşme başlamıştır. Bu yaşam tarzındaki asıl dönüşüm sanayi devrimi ile gerçekleşmiştir. Sanayi devrimi bize modernleşmenin kapılarını aralayan yeni bir dönemdir. ${ }^{43}$ Sanayi devrimi sonrasında her alanda karşımıza çıkan modernleşme, İslam'ın bize çizdiği sınırları aşarak pek çok ilkeyi ihlal etmemize sebep olmuştur.

Abdurrahman Arslan kitabında dünyaya Müslümanca bir bakış açısı sergilemeyen Müslümanların tutumlarını eleştirmektedir. Arslan, Hıristiyanların sandalye üzerinde yaptığı ibadet ile yemek masasında yenen yemek ve sırada görülen eğitim arasında bir ilişki kurmaktadır. Oysaki İslami yaşam tarzında bunlar yerde yapılmaktadır. Arslan bunu, İslam dininde ibadetlerin yere secde edilerek yapılması ile ilişkilendirmiştir. Ayrıca Müslümanların mimari anlayışı da batılı zihin dünyasına göre şekillendiğini dile getirerek, bu durumda mahremiyetin göz ardı edildiğini ifade etmiştir. Bunu göre göre mimariye herhangi bir müdahalede bulunmayan Müslümanların, Müslümanca bir bakış açısına sahip olmadığı ve batılı zihniyetin esiri olduğunu söylenebilir. ${ }^{44}$

41 Muhammed Çakır, "Soysal Medya ve Gösteri”, Sosyal Medya Araştırmaları-I, (ed.) Ali Büyükaslan, Ali Murat Kırık (2. bs., Konya: Çizgi Yayınları, 2017), s. 55-56.

42 Olgun Gündüz, “Toplumsal Değişme ve Mahremiyet Algısı”, Din Gelenek ve Ahlak Bağlamında Mahremiyet Algıları Sempozyumu (ed.) Yavuz Ünal v. dğr. (Samsun: Ordu İlahiyat Vakfı Yayını, 2015), c. I, s. 309311.

43 Şafak Kaypak, "Modernizmden Postmodernizme Değişen Kentleşme”, Küresel İktisat ve İşletme Çalşsmaları Dergisi, c. II, s. 4 (2013), s. 87-88.

44 Abdurrahman Arslan, Dünyaya Müslümanca Bakmak (2. b., İstanbul: Beyan Yayınları, y.y.), s. 58.

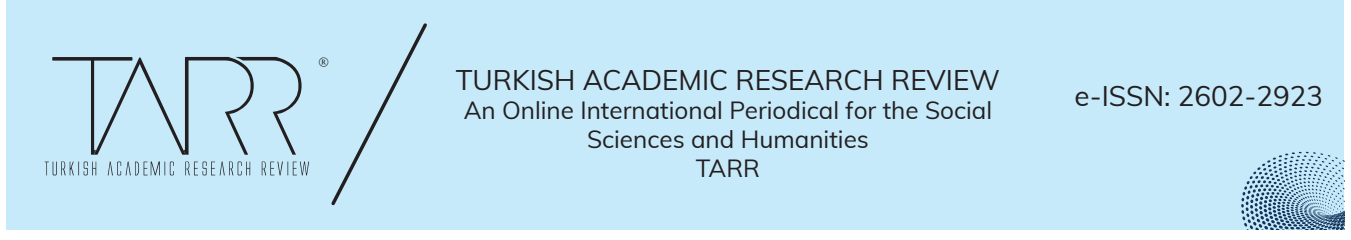


Zihinlerin gittikçe modernleşmesi teknoloji karşısındaki tutumumuzda açıkça ortaya çıkmaktadır. İnsanların televizyon ile yeni yeni tanışmaya başladığ 1 dönemlerde televizyon programlarında erkek gören ninelerimiz başlarını örterken, ${ }^{45}$ günümüzde o ninelerin yerini kendisini sosyal medya hesapları üzerinden açığa vurmaktan çekinmeyen torunları almıştır. Bu durum, aradan geçen kısa bir zamana rağmen mahremiyette yaşanan bozulmanın ve bu bozulma ile birlikte ortaya çıkan normalleşmenin bir göstergesidir.

Sosyal medya kendisi yeni bir alan olduğu gibi günümüz modern dünyasında mahremiyetin de değişim ve dönüşüm yaşadığı yeni bir alandır. Sosyal medya hesaplarından paylaşılan fotoğraflar, yapılan yorumlar, fikirleri ifade etmek ad1na paylaşılan gönderiler açıkça mahremiyetin paylaşımı haline gelmiştir. Sosyal medya üzerinde mahremiyet konusundaki sorumluluğumuz sadece bu paylaşımlarla da sınırlı değildir. Bu paylaşımlar dışında kullanıcılar, diğer kullanıcılar ile iletişimde bulunurken hangi hususlara ne ölçüde riayet etmeleri gerektiğinin bilincinde olmalıdırlar.

Sosyal medyada en çok ihlal edilen alanların başında tesettür gelmektedir. En geniş anlamda "örtmek", "gizlemek" manalarına gelen tesettür, insanın en tabi ihtiyaçlarından birisidir. Fıtrattan gelen örtünme duygusu insanlık tarihi kadar eski bir durumdur. İnsan, kendisini olumsuz hava şartlarından korumak isteyip örtünebilir. Ancak bu, fitrattan gelen bir istek değildir. Bundan dolayı örtünme, mahremiyetten kaynaklı hayâ duygusunun bir gereği olarak anlaşılmalıdır. ${ }^{46}$ Peygamber efendimiz de bu hususta hayânın imani bir gereklilik olduğunu beyan etmiştir. ${ }^{47}$ Örtünme güdüsünün ilk örneği Hz. Âdem ve Hz. Havva'dır. Şeytan'ın verdiği vesvese ile yasak meyveden yemeleri sonucu edep yerleri açılan Hz. Âdem ve Hz. Havva, cennet yaprakları ile edep yerlerini örtmenin telaşına düşmüşlerdir. ${ }^{48}$ Onların bu davranışından anlaşılacağı üzere mahremiyet duygusu ilk insanlıkla birlikte ortaya çıkan fıtri bir olgudur.

Örtünme ile ilgili olarak Kur’an-ı Kerim’de pek çok bilgi karşımıza çıkmaktadır. Bu emrin uygulaması olarak da Peygamber efendimiz ve ashabın yaşantısı bize örnek olmuştur. ${ }^{49}$ Yabancı kişilerin görmesinin günah olduğu ve gerek namaz sırasında gerek namaz dışında açılmaması gereken yerler fıkhi açıdan "avret” kelimesi ile ifade edilmektedir. ${ }^{50}$ Fıkıh kitaplarında da kadının erkeğe, erkeğin de kadına bakması mubah olan avret yerleri ayrıntılı şekilde ele alınmıştır. ${ }^{\circ 1}$ İnsan, bedeni üzerinde sınırsız yetki sahibi değildir. Bu yüzden taşıdığı bedenin emanet ol-

45 Cihan Aktaş, Mahremiyetin Tükenişi (İstanbul: Nehir Yayınları, 1995), s. 61.

46 H. Yunus Apaydın, “Tesettür”, Türkiye Diyanet Vakfı İslam Ansiklopedisi (DİA) (Ankara: Türkiye Diyanet Vakfi, 2011), XL, 538.

47 Bkz. Müslim, İman, 59.

48 Bkz. Tâhâ 20/121; A'râf 7/22.

49 Ayrıntılı bilgi için bkz. Emine Gümüş Böke, “İslam Hukuku’nda Kiyafet-Örtünme ve Kıyafetler Üzerine Resim ve Yazıların Durumu”, Kırıkale İslami İlimler Fakültesi (KïIFAD), s. 2 (2007), s. 27-30.

50 Mehmet Şener, "Avret”, Türkiye Diyanet Vakfı İslam Ansiklopedisi (DİA) (İstanbul: Türkiye Diyanet Vakfı, 1991), c. IV, s. 125.

51 Bkz. Ebû Bekr Şemsü'l-Eimme Muhammed b. Ebî Sehl Ahmed es-Serahsî, el-Mebsût (Beyrut: Daru'l Marife, 1993), c. X, s. 148-152.

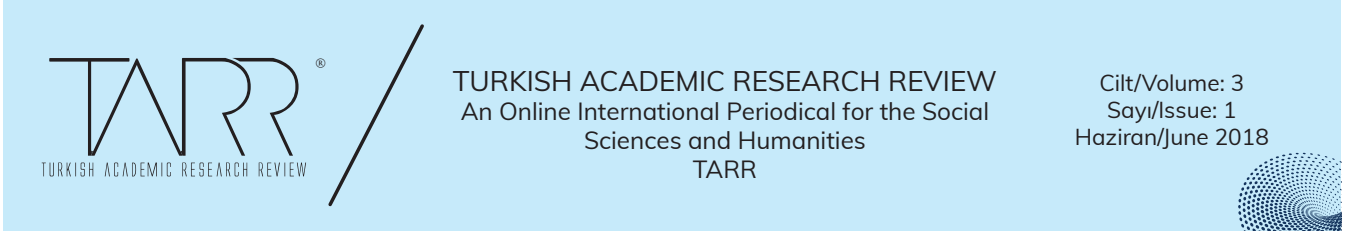


duğu bilincinde hareket etmesi gerekmektedir. Şayet bir yetkisi olacaksa dahi bu yetkinin ne derecede kullanılacağ1 örtünme hususunda olduğu gibi emanetin sahibi tarafından belirlenmelidir. ${ }^{52}$

Görüldüğü gibi İslam dini insanın bedenine ve onun değerini korumaya önem vermiş ve bu hususta önlemler almıştır. Mahremiyet ve tesettür de bu önlemlerin başlıca olanlarıdır. Ancak sosyal medya hesaplarına baktığımız zaman Allah'ın korunmasını istediği bedenlerin, sosyal medya kullanıcıları tarafından sergilenmekten çekinilmediğini görüyoruz. Mahremiyeti tehdit eden pek çok durum artık bu sanal ağlar üzerinde normalleşmiştir. Muhakkak ki birçok kullanıcı sosyal medya üzerinde rahatlıkla paylaştığı bu fotoğrafların, normal zamanlarda yabancı kişilerin elinde olmasından veya hiç tanımadığı bir kişinin evinin duvarlarında asılı olmasından hoşlanmayacaktır. Aslında sosyal medyada paylaşılan fotoğrafların da bu durumdan bir farkı yoktur. Ancak sosyal medyada kullanıcıların kendilerini teşhir ederek paylaştığı fotoğrafların bu şekilde sergileniyor olması normal karşılanmaktadır. ${ }^{53}$ Kullanıcılar hesaplarının gizli olmasının veya sadece tanıdığı insanlara açık olmasının rahatlığı içerisinde olabilirler. Fakat paylaşılan bu fotoğraflar rahatlıkla üçüncü kişilerin eline geçebilir ve böylece kolaylıkla pek çok yabancı gözün gözetimi altına girebilir.

Sosyal medyada mahremiyetin giderek yok oluş sebeplerinden birisi de modadır. Nur suresi 31. ayette Allah kadınlardan ziynet (yer)lerini açmamalarını istemiştir. Konumuz açısından "ziynet" ifadesi önem arz etmektedir. Ziynet kelimesi kullanıldığında akla gelecek ilk anlam "süs" veya "süs eşyası" olacaktır. Ancak burada ziynet ifadesi ile kastedilen anlam tesettürdür. Süs eşyasının kendisinin gözükmesinde bir sakınca olmayacağı için burada ziynet ifadesi ile kastedilen süs eşyaların vücutta bulunduğu yerler, yani insan bedeni üzerinde örtünmesi gereken yerlerdir. ${ }^{\circ}$ 乏 İslam âlimleri bu yerlerin gizli olup bilezik, halhal, boyunluk gibi süs eşyalarının takıldığı yerler olduğunu ifade etmişlerdir. ${ }^{55}$ Elbisenin de ziynet sayılabileceği ama burada bu anlamın istisna edildiği belirtilmiştir. ${ }^{56}$ Bundan dolayı diyebiliriz ki ziynet ifadesi anlam olarak iki duruma işaret edebilir. Birincisi kad1nın vücudunun güzelliğini içeren ziynet, yani kadının kendi zerafeti iken, ikincisi ise giyindikten sonra kıyafetiyle ve taktıkları ile meydana gelen ziynettir. ${ }^{57}$

Allah Teâlâ kadınlara mahremi olmayan kişilere karşı örtmeleri gereken yerleri ayet-i kerimede beyan ederken ${ }^{58}$ bizler sosyal medya hesapları üzerinde tesettürlü

52 Mustafa Şentürk, “Kur'an’da Beden Mahremiyetini İfade Eden temel Kavramlar”, Ordu Üniversitesi Sosyal Bilimler Araştırmaları Dergisi, c. VII, s. 2 (2017), s. 102.

53 Abdülaziz Kıranşal, Gençler İçin Sosyal Medya İlmihali (6. bs., Ankara: MGV Yayınları), s. 49-50.

54 Apaydın, "Tesettür", XL, 539.

55 Ebû İshâk İbrâhîm b. es-Serî b. Sehl ez-Zeccâc el-Bağdâdî, Me'ani'l Kur'an ve İrabüh, thk. Abdulcelil Abduhu Şelbî (Beyrut: Âlemü'l Kutub, 1988), c. IV, s.39.

56 Ebû Muhammed Abdülhak b. Gālib b. Abdirrahmân b. Gālib el-Muhâribî el-Girnâtî el-Endelüsî, el Muharrerü'l Veciz fi Tefsiril Kitabi'l Azîz, thk. Abdüsselâm Abdüşşâfi Muhammed (Beyrut: Daru'l Kutubi'l-İlmiyye), c. III, s. 293.

57 Muhammed Ali Sâbûnî, Kur'an-ı Kerim’in Ahkâm Tefsiri (çev. Mazhar Taşkesenlioğlu, İstanbul: Şamil Yayınlar1, 1984), c. II, s. 172-173.

58 Bkz. Nûr 24/31.

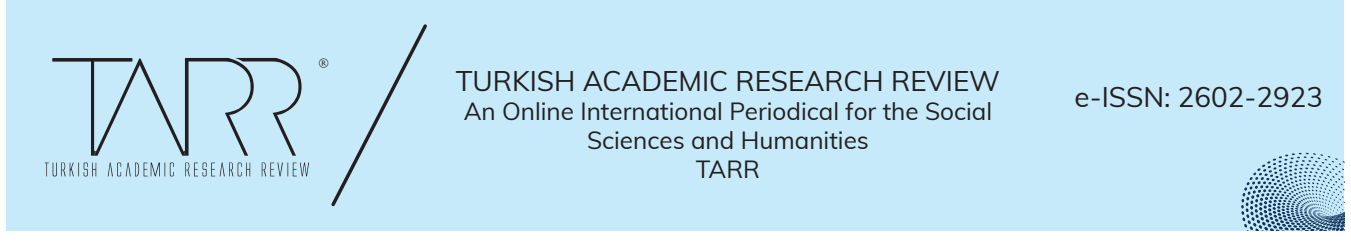


kadınların eşarp tanıtım videolarında eşarpların nasıl daha pratik kullanılacağını gösterirken boyunlarını göstermekten çekinmediklerine şahitlik ediyoruz. Tesettür ürünlerinin tanıtımını yaparken kendi tesettüründen taviz veriyor olmak tezat gözükmektedir. Oysaki ayet-i kerimede geçen şekli ile ziynet yerleri içerisinde kadınların boyunları da bulunmaktadır. Bu videolar sadece kendi cinsleri tarafından izlenmeyip, kendi mahremi dışındaki erkekler tarafından da izleniyor olmasına rağmen kadınlar kendilerini teşhir etmekten, ziynet yerlerinin göstermekten çekinmemekteler. Oysaki bir erkeğin kendisine yabancı bir kadının eli ve yüzü dışında diğer yerlerine bakması dinen caiz değildir. ${ }^{59}$ Bu saydığımız yerlere bakmak şayet fitneye sebebiyet verecekse bu durumda bu yerlere de bakmak caiz görülmemişken ${ }^{60}$ sosyal medyada bu ve bunun gibi İslam'in ortaya koyduğu pek çok esas zarar görmektedir.

Sosyal medyada mahremiyet ihlallerinden birisi de iki kişi arasında geçen özel bir durumun sosyal medya vasitası ile yayılmasıdır. Peygamber efendimiz "Şüphesiz ki kıyamet gününde Allah indinde mevkii en kötü olacak insanlardan biri, karısı ile haşır neşir olup da sonra onun sırrını yayandır” buyurmuştur. ${ }^{61}$ Bundan dolayı bir kişinin mahremiyetini sanal ortamda paylaşması uygun değildir. Allah Teâlâ kadın ile erkeğin aralarının açılması durumunda aralarını bulmak adına hakem tayin edilmesini istemiştir. ${ }^{62} \mathrm{Bu}$ hakemler kadının ve kocanın ailesinden olmak üzere iki kişi olup, onların durumunu gözetebilecek nitelikli güvenilir kişilerden seçilirdi. ${ }^{63}$ Çünkü bu kişiler karı ve kocanın gerçek duygularını, durumlarını daha iyi bilmektedirler. ${ }^{64}$ Görüldüğü gibi kadın ile erkeğin arasında geçen bir husumet diğer aile fertlerine yayılmak yerine duruma vakıf olmak ve aralarını bulmak adına iki kişinin seçilmesi ile sınırlandırılmıştır. Oysaki sosyal medya hesaplarında görmeye alışık olduğumuz bu tür paylaşımlar mahrem sayılan sınırların ifşa edilmesi ve sıradanlaşması sonucunu doğurmaktadır.

Sıklıkla karşılaşılan durumlardan birisi de tecessüs ve giybettir. Ahlaki bir terim olan ve bir kimsenin rızası dışında onun özel hallerini araştırmak anlamına gelen tecessüs ${ }^{65}$ normal hayatta olduğu gibi sosyal medyada da sıklıkla karşımıza çıkmaktadır. Merak duygusu insanı başkalarının gizli kalmasını istediği özel durumlarını araştırmaya itmektedir. Allah Teâlâ bunun günah olduğunu açıkça ayet-i kerimede beyan etmiştir. ${ }^{66}$ Hucurat suresindeki bu ayet-i kerime zanna göre hareket etmenin günah olduğunu belirtmekle birlikte insanın içinde zuhur eden şüpheye göre hareket edemeyeceği ve buna göre hüküm verilemeyeceğini de ifade etmektedir. Yani insan içinde oluşan zanna göre bir olayı araştırma, açığa çıkarma

59 Ebü'l-Hüseyn Ahmed b. Ebî Bekr Muhammed b. Ahmed el-Kudûrî, Muhtasar'ul Kudûrî, thk. Kamil Muhammed Muhammed Avide (Daru'l Kutubi'l İlmiyye, 1997), s. 241.

60 es-Serahsi, el-Mebsût, s. 153.

61 Müslim, Nikâh 123.

62 Nisa $4 / 35$.

63 Ebu Abdillâh (Ebü'l-Fazl) Fahrüddîn Muhammed b. Ömer b. Hüseyn er-Râzî et-Taberistânî Tefsîr-i Kebîr Mefâtîhu’l Gayb (çev. Suat Yıldırım v. dğr., Ankara: Akçağ Yayınları, 1990), c. VIII, s. 25.

64 Elmalılı Muhammed Hamdi Yazır, Hak Dini Kur'an Dili (İstanbul: Eser Yayınları, y.y.) c. II, s. 1352.

65 Mustafa Çağrıcı, “Tecessüs”, Türkiye Diyanet Vakfı İslam Ansiklopedisi (DİA) (Ankara: Türkiye Diyanet Vakfi, 2011), XL, 246.

66 Bkz. Hucurât, 49/12.

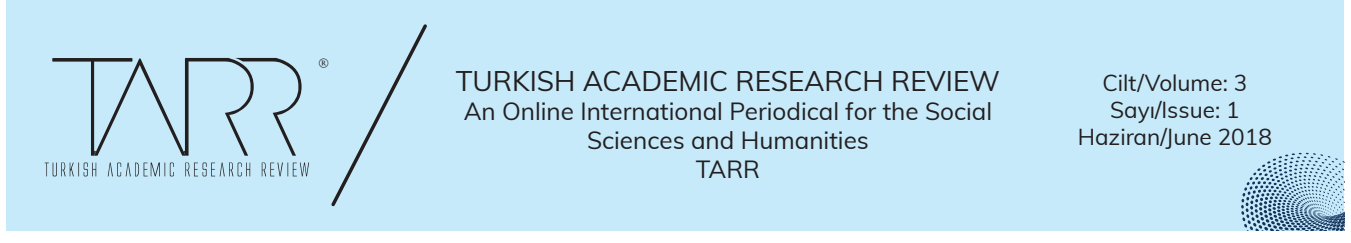


gibi bir eylemde bulunamaz. Böyle bir fiilde bulunmak, içinde bulunan zannı bir adım öteye taşıyarak olayın iç yüzünü öğrenmeye götürür ki tecessüs dediğimiz kavram bu şekilde açığa çıkmaktadır. ${ }^{\top v}$ Sosyal medya hesapları üzerinde başkalarının mesajlarını izinsiz okumak, başkalarının hesaplarına izinsiz girmek kişinin içinde oluşan zannı eyleme dökmesidir. Bu ise tecessüs olup kişinin mahremiyetinin zarar görmesi demektir.

Ayet-i kerimede "gıbet etmeyin" 68 şeklinde geçen ifade giybetin caiz olmadığını göstermektedir. Peygamber efendimiz de gıybeti "kardeşini hoşlanmadığın şeyle anmak"69 olarak tanımlamıştır. Klasik fıkıh kaynaklarında da gıybet konusu üzerinde durulmuş ve giybetin kerih görüldüğü ifade edilmiştir. Hakkında konuşulan kişinin bulunmadığı bir ortamda duyduğunda hoşlanmayacağı şeylerin arkasından konuşulmasının gıybet olduğu belirtilmiştir. Bu kimsenin hayatta olması veya ölü olması arasında bir fark yoktur. O kişi hakkında olumlu veya olumsuz konuşulan her şey; dini, dünyevi işleri, ailesi, edebi, kılık kıyafeti gibi hususlar hakkında konuşmak çirkin görülmüştür. Buradaki hikmet ise insan onurunu korumaktır. ${ }^{70}$ Sosyal medya üzerinde ise insanlar birbirleri hakkında bir başkasının duyduğunda hoşlanmayacağı şeyleri konuşmakta ve bunları paylaşmaktadırlar. Mesele sarf edilen bu konuşmalardaki vasıfların gerçekten o kişide bulunup bulunmaması değildir. Asıl mesele konuşulanların bir başkasının yüzüne söylenmeyip arkasından konuşuluyor olmasıdır. Duyulduğunda hoşlanılmayacak olan bu tarz konuşmalar insanın onur, şeref ve haysiyetini çiğnemektir. İşte bundan dolayı Allah Teâlâ gıybet etmeyi insanlara yasaklamıştır.

Sosyal medyada hesap açan her birey sosyal medyanın kendilerine sunmuş olduğu gizlilik ilkeleri ve verilerin nasıl kullanılacağını kabul etmiştir. Ancak bu durum kullanıcıların kendilerine ait her bilgiyi sosyal medya üzerinde alenileştirmesini gerekli kılmaz. Çünkü özel yaşamın gizliliği, üçüncü kişilerin ilgi alanından kendi mahremiyetimizi korumaktır. Yani bir sosyal medya kullanıcısı kendisine ait hallerin başkaları tarafından araştırılmasına imkân tanımaması gerekmektedir. ${ }^{71} \mathrm{Bu}$ durum mahremiyet ihlallerine sebebiyet verebilir.

"Yalnız kalma”, "baş başa kalma” gibi anlamlar içeren halvet, İslam hukukunda kadın ve erkeğin nikâh akdi sonrasında üçüncü kişilerin izin almadan giremeyeceği bir ortamda yalnız başlarına kalmalarını ifade etmektedir. ${ }^{72}$ Bu şekilde gerçekleşen halvet sonucunda kadının hangi durumda ne tür haklara sahip olacağı İslam hukukçuları tarafından ayrıntılı şekilde ele alınmış olup bunun yanında halvet-i sahihanın gerçekleşmemesi durumunda iddet, mehir gibi hususların da ne ölçüde

67 Seyyid Kutub, Fazılâl-îl Kur'an, (çev. İ Hakkı Şengüler, M. Emin Saraç, Bekir Karlıdağ, İstanbul: Hikmet Yayınlar1, 1968), c. XIII, s.502-503.

68 Hucurât, 49/12.

69 Müslim, Birr, 70.

70 Ebü'l-Abbâs Şihâbüddîn Ahmed b. İdrîs b. Abdirrahmân el-Misrî el-Karâfî, Envâru'l-Burûk fi Envâi'l-Furûk (Âlemu'l Kutub), c. IV, s. 229.

71 Halil İbrahim Acar, “Özel Hayatın Gizliliği ve Korunması”, Türkiye Günlüğü, Ankara, s. 62 (2000), s. 98.

72 Orhan Çeker, "Halvet”, Türkiye Diyanet Vakfı İslam Ansiklopedisi (DİA) (İstanbul: Türkiye Diyanet Vakfı, 2011), XV, 384.

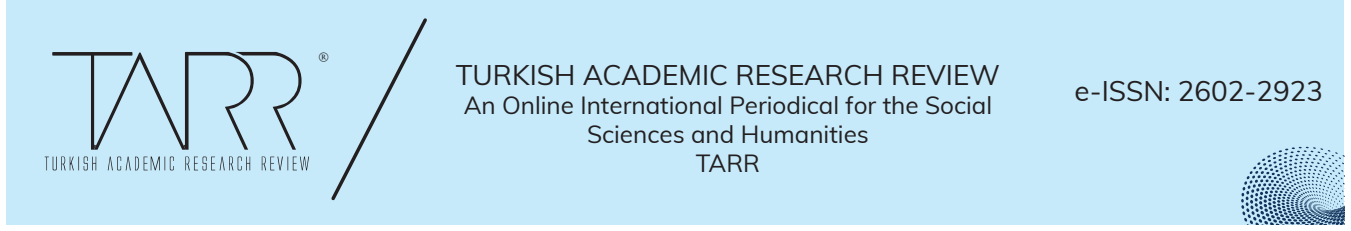


uygulanacağı belirlenmiştir. ${ }^{73}$ Aralarında nikâh akdi bulunmayan kimselerin ise kapalı bir ortamda yalnız başına kalmaları harama giden yolları önlemek adına uygun görülmemiştir. ${ }^{74}$ Sosyal medya hesapları üzerinden gönderilen mesajlar bu kapsamda ele alınırsa kadın ve erkek birbiri dışında kimsenin olmadığı bir ortamda mesajlaşmaktadır. Bu mesajlaşmalar "sanal halvet" olarak değerlendirilebilir ve sedd-i zerâi kapsamında ele alınabilir. Allah Teâlâ "zinaya yaklaşmayın"75 derken zina fiili ile birlikte zinaya sevk edecek her türlü durumdan onları uzak tutmayı istemiştir. ${ }^{76} \mathrm{Bu}$ hususta kadın ve erkeğin karşılıklı mesajlaşması, mesajlaşmayı gerektiren durumlarda sinırlara riayet etmek şartı ile sorunlu görülmese de karşı cinsi tahrik edici bir söz veya sanal ortamdaki yazışmalarda kullanılan ve emoji olarak isimlendirilen sanal şekiller ile karşı cinsin duygularını harekete geçiren ifadelerin kullanılması fıkhi açıdan uygun değildir. Çünkü bu türden yazışmalar karşı cinsi tahrik ederek harama götüren yolların önünü açabilir. Sedd-i zeâ-i kapsamında değerlendirilmesi de bundandır. Çünkü asıl olan fesada giden yolların önünü kapamaktır. ${ }^{\vee \vee}$ Bundan dolayı sosyal medya üzerinden mesajlaşmak aslen sakıncalı olmamakla birlikte kadın ve erkeğin mesajlaşması istenmeyen neticeler doğurabileceğinden dolayı uygun görülmemiştir.

Bedenin mahremiyeti denildiğinde sorumluluğumuz Allah'ın bize emrettiği hususlara riayet ederek yani tesettüre bürünerek bitmemektedir. Ayet-i kerimede hem kadınlar için hem de erkekler için gözlerini haramdan sakınmaları emredilmiştir. ${ }^{78}$ Allah'ın gözleri sakınmayı istemesinin nedeni fitneye sebebiyet verebilecek yolları kapamaktır. ${ }^{79}$ Çünkü mahremiyet sadece fiziksel olarak örtünmeden ibaret değildir. Örtünme ile beraber kişinin kendisini Allah'ın rızasına uygun olmayan her türlü bilgiden, görüntüden uzak tutmasıdır. Bu şekildeki mahremiyet kişiye kendi sınırları içerisinde sosyal bir alan tesis edecektir. ${ }^{80}$ Sosyal medya üzerinde paylaşılan fotoğraflara ve içeriklere de bu bakış açısı ile baktığımızda, paylaşılan fotoğraflar içerisinde fiziksel açıdan tesettüre uygun olanlar olabileceği gibi uygun olmayan fotoğraflarla da karşılaşabiliriz. Kendimiz tesettüre riayet ediyor olsak dahi diğer kullanıcılar mahremiyet bilinci ile hareket etmediği takdirde biz kendimizi Allah'ın rızasına uygun olmayan bilgiden ve görüntüden koruyamayı.

73 Bkz. Alâüddîn Ebû Bekr b. Mes'ûd b. Ahmed el-Kâsânî, Bedaiu's-Sanâi' fi Tertîbi'ş-Şerầ̂̀ (Daru’l Kutubi'l-İlmiyye, 1986), c. II, s. 291-292; Ebü’l-Hüseyn Ahmed b. Ebî Bekr Muhammed b. Ahmed el-Kudûrî, et-Tecrid (Kudûrî) thk. Merkezi el-Dirasati'l Fıkhiyye ve'l İktisadıyye (Kahire: Daru's-Selam, 2006, c. X s. 5303.

74 Çeker, "Halvet”, XV, 384.

75 İsra, 17/32.

76 Hayreddin Karaman v. dğr., Kur'an Yolu Türkçe Meâl ve Tefsir, Ankara: Diyanet İşleri Başkanlığı Yayınları, c. III (2007), s.480.

77 Ebü'l-Abbâs Şihâbüddîn Ahmed b. İdrîs b. Abdirrahmân el-Misrî el-Karâfî, ez-Zahîre (Beyrut: Daru'l Garbi'l İslamiyye), 1994, c. I, s. 102.

78 Nur 24/30,31

79 Seyyid Kutub, Fîzılâ'l-il-Kur'an, çev. İ. Hakkı Şengüler, M. Emin Saraç, Bekir Karlıdağ, İstanbul: Hikmet Yayınları, c. X (1968), s. 421.

80 Huriye Martı, "Hz. Peygamberin Hadislerinde Bir Değer Simgesi Olarak Beden ve Mahremiyet”, Marife Dergisi, s. 2 (2009), s. 10.

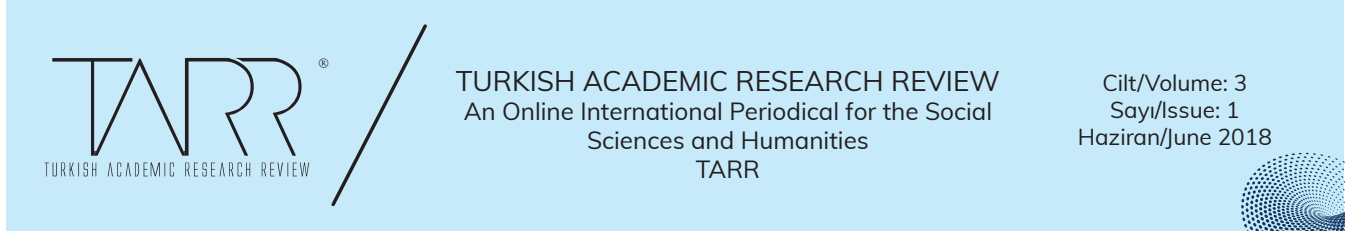


Sosyal medya üzerinde yapılan paylaşımlar sadece tesettüre riayet edilen veya edilmeyen fotoğraflardan da ibaret değildir. Bunların dışında gayri ahlaki fotoğraflar ve videolar da mevcuttur. Klasik fıkıh kitaplarında bakma ve işitme ile ilgili bahislere yer verilmiş ve nefsi şehvete sürükleyecek görüntülerden kaçınmak gerektiği, kulakları da her türlü kötülüğe meyletmekten korumak gerektiği belirtilmiştir. ${ }^{81}$ Buradan yola çıkarak diyebiliriz ki bu türden görüntülere kendimizi maruz bırakmak dinen ve ahlaken uygun değildir. Çünkü Allah Teâlâ kullarına "zinaya yaklaşmayın" 82 derken onları sadece zinadan men etmekle kalmayıp aynı zamanda zinaya yol açacak olan her türlü eylemden de men ettiğini ${ }^{83}$ söyledik. Sosyal medya üzerinde paylaşılan fotoğraflara ve videolara bu bakış açısı ile baktığımızda uygun içerikli olmayan pek çok görüntü bizi bu yola sevk edebilir. Peygamber efendimiz gözün de zinası olduğunu hatırlatarak "gözün zinası bakmaktır” 84 buyurmuştur. Bundan dolayı kişi kendisini dış etkilerden koruduğu gibi gözlerini de korumalıdır.

"İffetlerini korusunlar" 85 şeklinde ifade edilen ve ayet-i kerimede geçen şekli ile "ferc", herhangi bir kimse için teşhir edilmemesi gereken ve herhangi bir zorunluluk olmadan bakılmaması gereken bir yer olduğu hususunda İslam âlimleri ittifak etmiştir. ${ }^{86}$ Ferc kelime manası olarak cinsel organ anlamına gelmekle beraber mecaz olarak "iffet", "namus" anlamlarını da içermektedir.^v Yani korunması gereken yerler arasında kişinin iffeti ve namusu da bulunmaktadır.

Aile, İslam dininin en önem verdiği kurumların başında gelmektedir. Bu kurumun korunması için bazı önlemler alınmıştır. İffeti koruma da bu önlemlerin başında gelmektedir. ${ }^{88}$ Bundan dolayı Allah Teâlâ mümin kullarına, gözlerini kendilerine haram kılınan şeylerden sakınmayı emrederken, Peygamber efendimiz de bakışa bakış eklememek gerektiğini hatırlatmaktadır. Atılan ilk bakış irade dışında yani zaruretten gerçekleşirken kişi diğer bakışlarından sorumludur. ${ }^{89}$

Sosyal medya ile ilgili olarak görünür olmama, tesettüre dikkat etme üzerinde özellikle durulmalıdır. Çünkü yaşanan pek çok olumsuzluk ve ahlaki çöküntünün nedeni daha önce de ifade ettiğimiz gibi batılılaşma ve modernitedir. Batılı anlayışta mahremiyet "dokunma” üzerine kuruludur. ${ }^{90}$ Batılı anlayış görünür olmayı

81 Ebû Hâmid Muhammed b. Muhammed b. Muhammed b. Ahmed el-Gazzâlî et-Tûsî, Bidâyetü'l-Hidâye, thk. Doktor Muhammed Zainham Muhammed Azab (Kahire: Mektebetu Medbuli, 1993), s. 52.

82 İsra $17 / 32$.

83 Karaman, Kur'an Yolu Türkçe Meâl ve Tefsir, c. III, s. 480.

84 Müslim, Kader, 20.

85 Nûr, 24/30.

86 İbnü'l-Mülakkın Ebû Hafs Sirâcüddîn Ömer b. Alî b. Ahmed el-Ensârî el-Mısrî, Tavzih li Şerhi'l-Câmi'i's Sahîh, thk. Daru'l Felah li'l-Bahsi'l-İlmi ve Tahkiki't Türas (Dımeşk: Daru'l Nevadır, 2008), c. III, s. 239.

87 Hayreddin Karaman v. dğr., Kur'an Yolu Türkçe Meâl ve Tefsir (Ankara: Diyanet İşleri Başkanlığı Yayınları, 2008), c. IV, s.69.

88 Karaman, Kur'an Yolu Türkçe Meâl ve Tefsir, c. IV, s. 68-69.

89 Ebû Bekr Ahmed b. Alî er-Râzî el-Cessâs el-Hanefi Ahkamu’l Kur'an, thk. Abdusselam Muhammed Ali Şahin (Beyrut:Daru’l Kütübü’l İlmiyye, 1994), c. III, s. 408.

90 Soner Yağlı, "Yeni Medyada Örtük Olanın İfşası ve Gözetlenen Mahremiyetin Dönüşümü”, I. Uluslararası Yeni Medya- Yeni Yaklaşımlar Konferansı "Sosyal Medya ve Yeni Yaklaşımlar", (ed.) Tevhid Ayengil (Çanakkale: ÇOMÜ Matbaa, 2015), s. 290.

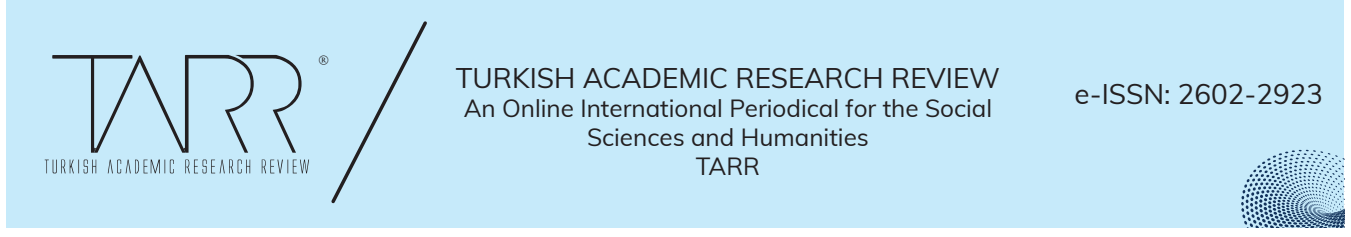


mahremiyetin ihlali olarak görmediğinden dolayı modernleşmeyi, batılılaşmayı yanlış anlayan pek çok Müslüman, yanlış batılılaşmanın bir sonucu olarak Allah'ın belirlediği sınırları sosyal medya üzerinde ihlal etmektedir.

Sosyal medya üzerinde yapılan paylaşımların içerikleri de ayrı bir önem arz etmektedir. İnsan yapıp ettiklerinde özgürken, bu özgürlügü̈n belli bir sınırı vardır ve bu sınır Rabbimiz tarafından kulları için çizilmiştir. Aynı durum sanal ortamlar için de geçerlidir. Sanal âlemde insan sınırsız yetki sahibi değildir. Çünkü insan farkında olmadan dış etkenlerin tesiri altında kalabilir. Bu durum, sanal ortamda duygu ve düşünceleri ifade ettiğimiz gönderilerde de kendisini göstermektedir. Zaman zaman bu ortamlarda dini hakaret içeren paylaşımlar karşımıza çıkmaktadır. Dini hakaret içeren bu paylaşımlar, dinden çıkmak anlamındaki "irtidad"91 kelimesi ile açılanabilir.

İslâm'da dinden dönme bazen sözle gerçekleşebileceği gibi bazen de fiille gerçekleşmektedir. Fiili terk kastidir ve dini değerlerle alay etmeyi içermektedir. Putlara tapmak, Kur'an'ı çirkin, uygunsuz yerlere atmak gibidir. ${ }^{92}$ Bir de itikadi terkten bahsedebiliriz ki bu İslam'ın temel esaslarına inanmamak şeklinde gerçekleşir. Ancak itikadi terkin cezayı gerektirmesi için kavli veya ameli olarak dışa vurulması gerekmektedir. Ancak bu şekildeki ridde cezayı gerektirir. ${ }^{93}$ Aynı şekilde Peygamber efendimiz de fiili olarak eyleme dökülmeyen veya sözle dile getirilmeyen şeylerde bir ceza gerekmediğini ${ }^{94}$ ümmetine haber vermiştir. Sosyal medya hesapları üzerinden din karşıtı yapılan her bir söylem, kişinin içindeki duygularının dışa vurmasıdır. Bundan dolayı bu türden paylaşımların fıkhi açıdan uygun olmadığını söyleyebiliriz. Çünkü ifade etmeye çalıştığımız üzere İslam hukukunda dinden çıkan kişiye herhangi bir ceza öngörülmemiştir. Ceza, içinde bulunduğu bu durumu fiilen uygulamaya geçiren veya sözle dişa vuran kişilere gerekmektedir. Bundaki amaç da dini ve toplumsal değerlerin korumaktır. Sosyal medya da din karşıtı söylemlerin hızla yayılması adına aracı rol görevi üstlenmektedir.

Sosyal medyada içerik paylaşımı konusunda değinilmesi gereken bir husus da başkasına ait bilgilerin izinsiz paylaşılıyor olmasıdır. Herhangi bir sosyal medya aracına üye olmak istendiğinde kullanıcılardan istenen belli başlı bilgiler vardır. $\mathrm{Bu}$ bilgiler içerisinde doldurulması zorunlu alanlar olduğu gibi doldurulması zorunlu olmayan, ama birçok kişinin yine de doldurarak özel bilgilerini paylaştığ alanlar vardır. Bu türden bilgilerin paylaşımı ise kişinin kendi mahremiyetini ihlal etmekle birlikte aile bilgilerinin paylaşılmasıyla birlikte başkalarının mahremiyetine de zarar vermektedir.

91 İrfan İnce, "Ridde", Türkiye Diyanet Vakfı İslam Ansiklopedisi (DİA) (İstanbul: Türkiye Diyanet Vakfı, 2008), XXXV, 88.

92 Ebû Zekeriyyâ Yahyâ b. Şeref b. Mürî en-Nevevî, Ravzatü't Tâlibîn ve Umdetü'l Müttakin, thk. Zuheyr eş-Şaviş (Beyrut: Mektebetu'l İslami, 1991), c. X, s. 64.

93 Abdülkadir Ûdeh, et-Teșrîu'l Cinẩiyyü'l İslâmi Mukârenen bi'l Kanuni'l Vad'i (Beyrut: Daru'l Katibi'l Arabi), c. II, s. 710-711.

94 Müslim, İman, 201.

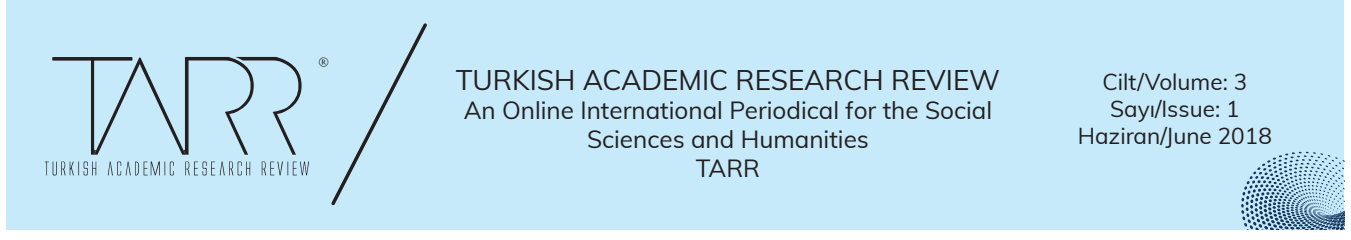


İzinsiz kişisel bilgi paylaşımı yanında sosyal medyada başkasına ait fikir ve görsel içerik paylaşımı da mevcuttur. Bu tür paylaşımlar başkasına ait bilginin izinsiz kullanımı olup bilginin hırsızlığı anlamına gelmektedir. İslâm hukukuna göre bir suçun hırsızlık kapsamında değerlendirilebilmesi için hırsızlığın rükünlerinin bulunması gerekmektedir. Bu rükünlerden birisi de malın gizlice alınması ve çalınan malın başka bir kimsenin mülkiyeti altında bulunmamasıdır. ${ }^{95}$ İzinsiz kullanılan bu bilgiler normal şartlarda telif hakkı ile koruma altındadır. Alıntı yapıldığı belirtilmeyen her bilgi, telif hakkı ile kişinin mülkiyeti altına geçmiş olan bilginin izinsiz kullanımını içermektedir. Hırsızlığın unsurlarından gizlice alınması izinsiz ve rıza dışı almayı içerdiğinden dolay1 ${ }^{96}$ buradan hareketle izinsiz paylaşılan, nereden alındığı belirtilmeyen her türlü içerik paylaşımı bilgi hırsızlığı olarak ifade edilebilir.

Sosyal medyada herkesin kendisine ait bir profil sayfası vardır. Bu sayfada kullanıcılar istedikleri gönderiyi paylaşabilirler. Bazı kullanıcılar kendisine ait olmayan fotoğrafları profiline koyarak kendi fotoğrafıymış gibi göstermektedirler. ${ }^{97}$ Bu durumu münafıklıkla bağdaştırılabilir. Çünkü Kur'an-1 Kerim'de de belirtildiği gibi aldatmak, hileye başvurmak gibi davranışlar münafıklık alametidir. ${ }^{98}$ Münafık kimsenin alameti "konuştuğu zaman yalan söyleyen kimse" olmasıdır. 99 Müslüman kimliğe sahip bir kimse hile ve aldatmacaya başvurmaz. Ancak sosyal medyada kimi kullanıcıların bu türden hilelere başvurduğu görülmektedir. Bu gibi hileli davranışlar Müslüman kimliğine sahip bir kimsenin uzak durması gereken davranışlardır.

Sosyal medya beden ve bilgi mahremiyetinin yanında mesken mahremiyeti anlay1şında da dönüşüm yaşatmıştır. Özellikle modernleşme ile birlikte toplumun belli bir kısmında evlerin mahrem alan olarak görülmesi anlayışı değişmiş ve başkaları tarafından görülmesi doğal karşılanır hale gelmiştir. ${ }^{100}$ Evlerin görülmesi ise beraberinde aile bireylerinin teşhirini getirmektedir. Mesken mahremiyeti, aile mahremiyetini de beraberinde getirdiğinden dolayı sosyal medyada mesken mahremiyetini ihlal eden bir kimsenin aile mahremiyetine de zarar verdiği söylenebilir.

İslam tarihinde evlere baktığımız zaman daima korunaklı, başkalarının gözetimine maruz kalmadan rahatça günlük yaşantıyı sürdürmeye elverişlidir 1 ' '. Günümüzde ise mesken mahremiyetinin gelişen teknolojik imkânlar ile daha çok ihlal edildiğini görüyoruz. Özellikle sosyal medyanın yaygınlaşması ile birlikte insanlar evlerini, paylaştıkları fotoğraflar ve videolar ile daha da görünür kılmıştır. $\mathrm{Bu}$

95 Bkz. Alâüddîn Ebû Bekr b. Mes'ûd b. Ahmed el-Kâsânî, Bedaiu's-Sanâi' fi Tertîbi'ş-Şerâ'î (Daru'l Kutubi’l İlmiyye, 1986), c. VII, s. 65.

96 Yaşar Yiğit, İslam Ceza Hukuku Hükümlerin Yürürlülüğü, (Ankara: Sistem Ofset Yayıncıllk, 2012), s. 69.

97 Kıranşal, a.g.e., s. 95.

98 Bkz. Bakara, 2/8; Bakara 2/14; Nisa 4/142; Enfâl 8/62.

99 Müslim, İman, 106.

100 Nevzat Aydın, Hadislerde Mesken Mahremiyetini Tehtit Eden Unsurlara Karşı Alınan Önlemler” EKEV Akademi Dergisi, s. 63 (2015), s. 288.

101 Salim Öğüt, "Harem”, Türkiye Diyanet Vakfı İslam Ansiklopedisi (DİA) (İstanbul: Türkiye Diyanet Vakfı, 1997), XVI, 127.

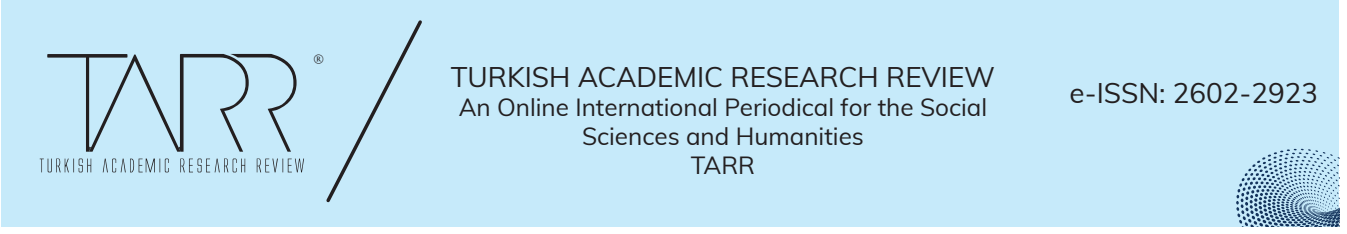


durum İslami hayat tarzının yavaş yavaş yok oluşuna işarettir. ${ }^{102}$ Beğenilme, takdir edilme duygusu ile yapılan bu paylaşımlar, mahremiyetin önemini yitirdiğini göstermektedir. Ailenin fiziki kalkanı görevini gören ve mahremiyetimizi yani özgürlügüumüzü doyasıya yaşadığımız evlerimiz, kendimizi tatmin etme arzusu ile paylaştığımız fotoğraflar ile yabancı gözlerin gözetimi altına bırakılmıştır. Böylece mesken mahremiyetine zarar vermekle her daim korumamiz gereken, her türlü eğitimin temellerinin atıldığ1 ailenin mahremiyeti sosyal medya üzerinde ihlal edilmektedir.

\section{Sonuç}

Sosyal medya yalnız zararları ile veya yalnız faydalı yönleri üzerinde durarak ele alınabilecek bir konu değildir. Sosyal medyayı bize faydalı kılan da zararlı kılan da onun ne amaçla kullanıldığıdır. Günümüzde sosyal medya daha çok vakit geçirip sosyalleşmek ve iletişim kurma amacı ile kullanılmaktadır. Ancak tüm bunları yaparken sosyal medyada mahremiyet anlayışında bir değişim yaşanmıştır. $\mathrm{Bu}$ değişim, farkına vardığımız veya farkında olmadan gerçekleştirdiğimiz beden, mesken ve bilgi mahremiyetindeki dönüşümdür. Bizler günlük yaşantımızı sürdürürken nasıl bir mahremiyet anlayışına sahipsek, sosyal medya üzerinde de aynı mahremiyet bilinci ile hareket etmemiz gerekmektedir. Çünkü sosyal medya dünyasına geçildiğinde Allah'a karşı olan sorumluluklarımız biraz daha artmaktadır.

Sosyal medya, kullanıcılarına pek çok tasarrufta bulunma imkânı vermektedir. Paylaşılan fotoğraflar, atılan mesajlar, yapılan yorumlarla birlikte geleneksel medyanın aksine daha hızlı ve interaktif bir iletişim ortamı sunmaktadır. Bu sanal ortamlar fıkhi açıdan değerlendirildiğinde ise sosyal medyada bazı kullanımlar, şu anki kullanım amacı ile birlikte mahzurlu görülmektedir. Ayet ve hadislerle birlikte klasik kaynaklara baktığımız zaman Allah'ın emrettiği şeylerden birisinin insanın bedenini ve bakışlarını dış etkenlere karşı korumak olduğu görüyoruz. Dinen mahremiyet olarak isimlendirilen bu emir ve yasaklar, Allah'in insan korumak amaçlı aldığ 1 tedbirlerdir. Klasik kaynaklara baktığımızda ise fukaha bu emirleri insanın onur şerefini korumak amaçlı ele almıştır.

Modernizm, batılılaşma veya teknolojik gelişmeler ne kadar mahremiyeti elimizden almaya çalışsa da bizim modern gelişmeler karşısındaki en güçlü kozumuzun aile olması gerekmektedir. Her türlü eğitimin temellerinin atıldığı aile kurumuna mahremiyet bilincinin sağlanması adına çokça görev düşmektedir. Mahremiyet kişinin kendi iradesi ile değil, her şeyin sahibi olan Allah'ın iradesi dâhilinde sınırları çizilmiş olup bize düşen bunun farkına varıp bu bilinç ile hareket etmektir.

\section{Kaynakça}

Acar, Halil İbrahim, “Özel Hayatın Gizliliği ve Korunması", Türkiye Günlüğü, Ankara, s. 62 (2000), s. 98.

Aktaş, Cihan, Mahremiyetin Tükenişi, İstanbul: Nehir Yayınları, 1995.

102 Aydın, a.g.e., s. 290.

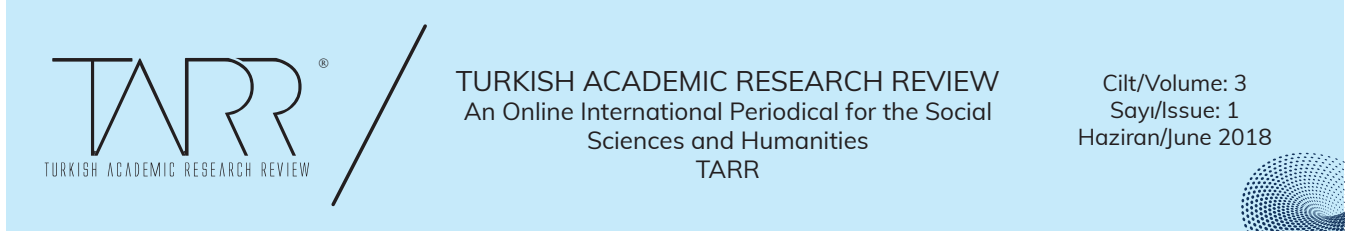


Apaydın, H. Yunus, “Tesettür”, Türkiye Diyanet Vakfı İslam Ansiklopedisi (DİA), Ankara: Türkiye Diyanet Vakf1, 2011, XL, 538.

Arslan, Abdurrahman, Dünyaya Müslümanca Bakmak, 2. b., İstanbul: Beyan Yayınları, y.y..

Atar, Fahrettin, "Nikah", Türkiye Diyanet Vakfı İslam Ansiklopedisi (DİA) İstanbul: Türkiye Diyanet Vakf1, 2007, XXXIII, 112.

Aydın, Nevzat, "Hadislerde Mesken Mahremiyetini Tehdit Eden Unsurlara Karşı Alınan Önlemler”, Ekev Akademi Dergisi, s. 63, 2015.

Babacan, Haşlak ve Hira, Mehmet Emin, İrfan, İsmail, "Sosyal Medya ve Arap Baharı", Akademik İncelemeler Dergisi, c. VI, s. 2, (2011).

Boynukalın, Ertuğrul, "Makâsıdü’ş-şerîa”, Türkiye Diyanet Vakfi İslam Ansiklopedisi (DİA), Ankara: Türkiye Diyanet Vakfı, 2003, XXVII.

Böke, Emine Gümüş, “İslam Hukuku'nda Kıyafet-Örtünme ve Kiyafetler Üzerine Resim ve Yazıların Durumu”, Kırıkkale İslami İlimler Fakültesi (KİIFAD), s. 2 (2007).

Cerrah, Lokman, "Sosyal Medya ve Bazı Kurumsal Etkileşimler ve Sosyal Medyaya Eleștirel Yaklaşım”, Atatürk Üniversitesi Sosyal Bilimler Enstitüsü Dergisi, c. IV, s. 20 (2016).

Çağrıcı, Mustafa, "İffet”, Türkiye Diyanet Vakfı İslam Ansiklopedisi (DİA), Ankara: Türkiye Diyanet Vakfi, 2000, XXI.

Çağrıcı, Mustafa, “Tecessüs”, Türkiye Diyanet Vakfı İslam Ansiklopedisi (DİA), İstanbul: Türkiye Diyanet Vakfı, 2011, XL.

Çakır, Muhammed, "Soysal Medya ve Gösteri”, Sosyal Medya Araștırmaları-I, (ed.) Ali Büyükaslan, Ali Murat Kırık, 2. bs., Konya:Çizgi Yayınları, 2017.

Çeker, Orhan, "Halvet”, Türkiye Diyanet Vakfi İslam Ansiklopedisi (DİA), İstanbul: Türkiye Diyanet Vakf1, 2011, XV.

Dağıtmaç, Murat, Sosyal Medya Bizi Neden Kullanır, İstanbul: Metafoz Yayınları, 2015.

Davudoğlu, Ahmed, Sahih Müslim Tercemesi ve Şerhi, İstanbul: Sönmez Yayınları, c. I, 1980; İstanbul: Sönmez Yayınları c. VII, 1977; İstanbul: Sönmez Yayınları c. X, 1983.

Develioğlu, Ferit, Osmanlıca-Türkçe Ansiklopedik Lûgat, 2. bs., Ankara: y.y. 1970.

el-Cessâs, Ebû Bekr Ahmed b. Alî er-Râzî, Ahkamu'l Kur'an, thk. Abdusselam Muhammed Ali Şahin, Beyrut: Daru'l Kütübü'l İlmiyye, 1994, c. III.

el-Gazzâlî, Ebû Hâmid Muhammed b. Muhammed b. Muhammed b. Ahmed, Bidâyetü’lHidâye, thk. Doktor Muhammed Zainham Muhammed Azab Kahire: Mektebetu Medbuli, 1993.

el-Karâfî, Ebü'l-Abbâs Şihâbüddîn Ahmed b. İdrîs b. Abdirrahmân el-Misrî, ez-Zahîre, Beyrut: Daru'l Garbi’l İslamiyye, 1994, c. I.

el-Karâfî, Ebü'l-Abbâs Şihâbüddîn Ahmed b. İdrîs b. Abdirrahmân el-Misrî, Envâru'lBurûk fi Envâi'l-Furûk, Âlemu'l Kutub, c. IV.

el-Kâsânî, Alâüddîn Ebû Bekr b. Mes'ûd b. Ahmed, Bedaiu's-Sanâi' fi Tertîbi'ş-Şerâ'î, Daru'l Kutubi'l-İlmiyye, $\neg \wedge \uparrow$ ।, c. II-VII.

el-Kudûrî, Ebü’l-Hüseyn Ahmed b. Ebî Bekr Muhammed b. Ahmed, et-Tecrid (Kudûrî) thk. Merkezi el-Dirasati'l Fıkhiyye ve'l İktisadıyye, Kahire: Daru's-Selam, 2006, c. $\mathrm{X}$.

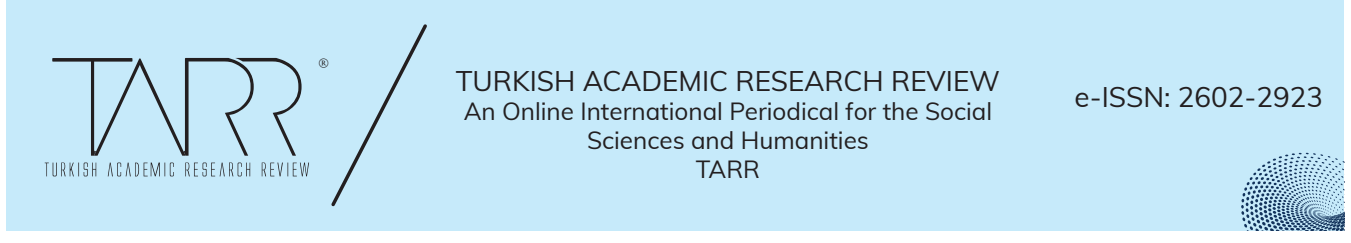


el-Kudûrî, Ebü’l-Hüseyn Ahmed b. Ebî Bekr Muhammed b. Ahmed, Muhtasar'ul Kudûrî, thk. Kamil Muhammed Muhammed Avide, Daru'l Kutubi'l İlmiyye, 1997.

en-Nevevî, Ebû Zekeriyyâ Yahyâ b. Şeref b. Mürî, Ravzatü't Tâlibîn ve Umdetü'l Müttakin, thk. Zuheyr eş-Şaviş Beyrut: Mektebetu’l İslâmi, 1991, c. X.

Erdoğan, Mehmet, Fikıh ve Hukuk Terimleri Sözlüğü, 4. bs., İstanbul: Ensar Yayınları, 2013.

Erdoğan, Mehmet, İslam Hukukunda Ahkâmın Değisşmesi, 6. bs., İstanbul: Marmara Üniversitesi İlahiyat Vakf1 Yayınları, 2009.

er-Râzî, Ebu Abdillâh (Ebü'l-Fazl) Fahrüddîn Muhammed b. Ömer b. Hüseyn, Tefsîr-i Kebîr Mefâtîhu'l Gayb, çev. Suat Yıldırım v. dğr., Ankara: Akçağ Yayınları, 1990, c. VIII.

es-Serahsî, Ebû Bekr Şemsü'l-Eimme Muhammed b. Ebî Sehl Ahmed, el-Mebsût, Beyrut: Daru'l Marife, 1993, c. X.

ez-Zeccâc, Ebû İshâk İbrâhîm b. es-Serî b. Sehl, el-Bağdâdî, Me'ani'l Kur'an ve İrabüh, thk. Abdulcelil Abduhu Şelbî, Beyrut: Âlemü'l Kutub, 1988, c. IV.

Güllük, İsmail, Avret Mahremiyeti Prensipleri Açısından Görüntü Gerçeklik, Sanal Âlem ve Cinsellik Üzerine Fıkhî Bir Analiz” İslam Hukuku Araştırmaları Dergisi, s.23 (2014).

Gündüz, Olgun, “Toplumsal Değişme ve Mahremiyet Algısı”, Din Gelenek ve Ahlak Bağlamında Mahremiyet Algıları Sempozyumu, (ed.) Yavuz Ünal v. dğr., Samsun: Ordu İlahiyat Vakfı Yayını, c. I (2015).

http://www.mevzuat.gov.tr/Metin.Aspx?MevzuatKod=1.5.5187\&MevzuatIliski=0\&sourceXmlSearch = , (22.05.18).

http://www.mevzuat.gov.tr/MevzuatMetin/1.5.5237.pdf , (23.05.18).

https://wearesocial.com/blog/2018/01/global-digital-report-2018, erişim tarihi:07.02.18.

İbn Atiyye, Ebû Muhammed Abdülhak b. Gālib b. Abdirrahmân b. Gālib el-Muhâribî elGırnâtî el-Endelüsî, el Muharrerü'l Veciz fi Tefsiril Kitabi'l Azìz, , thk. Abdüsselâm Abdüşşâfi Mauhammed Beyrut: Daru'l Kutubi'l-İlmiyye, c. III.

İbnü'l-Mulakkın, Ebû Hafs Sirâcüddîn Ömer b. Alî b. Ahmed el-Ensârî el-Misrî, Tavzih li Şerhi'l-Câmi'i's Sahîh, thk. Daru'l Felah li'l-Bahsi'l-İlmi ve Tahkiki't Türas, Dımeşk: Daru'l Nevadır, 2008, c. III.

İnce, İrfan, "Ridde", Türkiye Diyanet Vakfı İslam Ansiklopedisi (DİA), İstanbul: Türkiye Diyanet Vakf1, 2008, XXXV.

Kahraman, Abdullah, "Mahremiyetin Tanımı ve Sınırı", Din Gelenek ve Ahlak Bağlamında Mahremiyet Algiları Sempozyumu, ed. Yavuz Ünal vd., Samsun: Ordu İlahiyat Vakfı Yayını C. I (2015).

Karaman Hayreddin v. dğr., Kur'an Yolu Türkçe Meâl ve Tefsir, Ankara: Diyanet İșleri Başkanlığı Yayınları, c. III, 2007; Ankara: Diyanet İşleri Başkanlığı Yayınları c. IV, 2008; Ankara: Diyanet İşleri Başkanlığı Yayınları c. V, 2008.

Kartal, Mehmet, “Türkiye'de Sosyal Medya Raporu”, İletişim ve Diplomasi Dergisi, s. 1 (2013).

Kaypak, Şafak, "Modernizmden Postmodernizme Değişen Kentleşme”, Küresel İktisat ve İşletme Çalışmaları Dergisi, c. II, s. 4 (2013).

Kıranşal, Abdülaziz, Gençler İçin Sosyal Medya İlmihali, 6. bs., Ankara: MGV Yayınları.

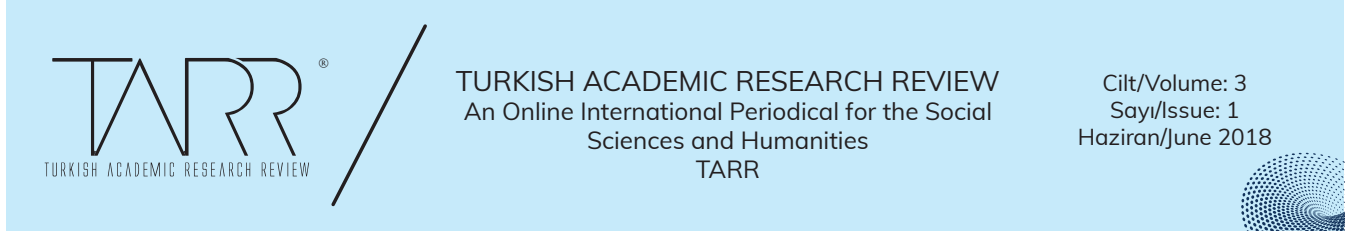


Kutub, Seyyid, Fazılâl-îl Kur'an, çev. İ. Hakkı Şengüler, M. Emin Saraç, Bekir Karlıdağ, İstanbul: Hikmet Yayınları, 1968, c. X; İstanbul: Hikmet Yayınları, 1968, c. XIII.

Martı, Huriye, "Hz. Peygamberin Hadislerinde Bir Değer Simgesi Olarak Beden ve Mahremiyet”, Marife Dergisi, s. 2 (2009).

Öğüt, Salim, "Harem", Türkiye Diyanet Vakfı İslam Ansiklopedisi (DİA), İstanbul: Türkiye Diyanet Vakf1, 1997, XVI.

Öztürk, Şerife, "Sosyal Medyada Etik Sorunlar”, Selçuk İletişim Dergisi, c. I, s. 9 (2015).

Öztürk, Tuba, "Mahremiyet Sınırlarının Değişimi: Hz. Peygamber' in Özel Hayat Örneği”, Türkiye'de Tüm Yönleri ile Siyer Çalışmaları Sempozyum Tebliğler Kitabı I, ed. Hatice Sarı Tan, İstanbul: Meridyen Derneği Yayınları, c. I (2016).

Özutku, Fatih v. dğr., Sosyal Medyanın ABC'si, İstanbul: Alfa Yayınları, 2014.

Sâbûnî, Muhammed Ali, Kur'an-ı Kerim'in Ahkâm Tefsiri, çev. Mazhar Taşkesenlioğlu, İstanbul: Şamil Yayınları, c. II (1984).

Şener, Mehmet, “Avret”, Türkiye Diyanet Vakfi İslam Ansiklopedisi (DİA), İstanbul: Türkiye Diyanet Vakf1, 1991, IV.

Şentürk, Mustafa, "Kur'an'da Beden Mahremiyetini İfade Eden temel Kavramlar", Ordu Üniversitesi Sosyal Bilimler Araștırmaları Dergisi, c. VII, s. 2 (2017).

Ûdeh, Abdülkadir, et-Teșrîu'l Cinẩiyyü'l İslâmi Mukârenen bi'l Kanuni'l Vad'i, Beyrut: Daru'l Katibi'l Arabi, c. II.

Yağlı, Soner, "Yeni Medyada Örtük Olanın İfşası ve Gözetlenen Mahremiyetin Dönüşümü", I. Uluslararası Yeni Medya- Yeni Yaklassımlar Konferansı "Sosyal Medya ve Yeni Yaklaşımlar", (ed.) Tevhid Ayengil, Çanakkale: ÇOMÜ Matbaa, 2015.

Yazır, Elmalıı Muhammed Hamdi, Hak Dini Kur'an Dili, İstanbul: Eser Yayınları, y.y., c. II.

Yeniçıktı, Nagihan Tufan, Sosyal Medya Facebook ve Twitter Motivasyonları, Konya: Literatürk Akademi, 2017.

Yiğit, Yaşar, İslam Ceza Hukuku Hükümlerin Yürürlüğü, Ankara: Sistem Ofset Yayıncılık, 2012.

Yüksel, Mehmet, "Mahremiyet Hakkı ve Sosyo-Tarihsel Gelișimi”, Ankara Üniversitesi SBF Dergisi, c. LVIII s. 1 (2003). 